\title{
HBX sensitizes hepatocellular carcinoma cells to lapatinib by up-regulating ErbB3
}

\author{
Jhen-Yu Chen ${ }^{1,2, *}$, Yun-Ju Chen ${ }^{3,4,5, *}$, Chia-Jui Yen ${ }^{6}$, Wen-Shu Chen', Wei-Chien \\ Huang $1,2,7,8$ \\ ${ }^{1}$ The Ph.D. Program for Cancer Biology and Drug Discovery, China Medical University and Academia Sinica, Taichung, Taiwan \\ ${ }^{2}$ Graduate Institute of Cancer Biology, China Medical University, Taichung, Taiwan \\ ${ }^{3}$ Department of Biological Science \& Technology, I-Shou University, Kaohsiung, Taiwan \\ ${ }^{4}$ School of Medicine for International Students, I-Shou University, Kaohsiung, Taiwan \\ ${ }^{5}$ Department of Medical Research, E-Da Hospital, Kaohsiung, Taiwan \\ ${ }^{6}$ Internal Medicine, National Cheng-Kung University, Tainan, Taiwan \\ ${ }^{7}$ Center for Molecular Medicine, China Medical University and Hospital, Taichung, Taiwan \\ ${ }^{8}$ Department of Biotechnology, Asia University, Taichung, Taiwan \\ ${ }^{*}$ These authors have contributed equally to this work \\ Correspondence to: Wei-Chien Huang, e-mail: whuang@mail.cmu.edu.tw
}

Keywords: HBx, hepatocellular carcinoma, EGFR family, lapatinib, target therapy

Received: June 01,2015 Accepted: November 06, $2015 \quad$ Published: November 16, 2015

\section{ABSTRACT}

Poor prognosis of hepatitis B virus (HBV)-associated hepatocellular carcinoma (HCC) involves HBV X protein (HBX)-induced tumor progression. HBx also contributes to chemo-resistance via inducing the expressions of anti-apoptosis and multiple drug resistance genes. However, the impact of HBx expression on the therapeutic efficacy of various receptor tyrosine kinase inhibitors remains unknown. In this study, our data showed that HBx overexpression did not alter the cellular sensitivity of HCC cell lines to sorafenib but unexpectedly enhanced the cell death induced by EGFR family inhibitors, including gefitinib, erlotinib, and lapatinib due to ErbB3 up-regulation. Mechanistically, HBx transcriptionally up-regulates ErbB3 expression in a NF-kB dependent manner. In addition, HBx also physically interacts with ErbB2 and ErbB3 proteins and enhances the formation of ErbB2/ErbB3 heterodimeric complex. The cell viability of HBx-overexpressing cells was decreased by silencing ErbB3 expression, further revealing the pivotal role of ErbB3 in $\mathrm{HBX}$-mediated cell survival. Our data suggest that HBX shifts the oncogenic addiction of HCC cells to ErbB2/ErbB3 signaling pathway via inducing ErbB3 expression and thereby enhances their sensitivity to EGFR/ErbB2 inhibitors.

\section{INTRODUCTION}

Hepatocellular carcinoma, the most malignant type of liver cancers, is the third leading cancer-related mortality [1]. Hepatitis B virus (HBV) and Hepatitis C virus $(\mathrm{HCV})$ infections cause cirrhosis and subsequently contribute to the tumorigenesis in most of HCC patients [2]. These risk factors inactivate p53 transcriptional functions, induce inflammation response, and produce oxidative stress to promote HCC development by increasing cell proliferation, loss of growth, and genetic alternation $[3,4]$. HBV, the first virus found to associate with human cancer, contributes to HCC development in Asia and South Africa. HBV-associated HCC is characterized by highly chemotherapy resistance $[5,6]$. HBV $\mathrm{X}$ protein $(\mathrm{HBx})$ is encoded in the smallest open reading frame $\mathrm{X}$, and has been well demonstrated to play a critical role in HBV-induced HCC development. HBx also mediates chemo-resistance in HCC by modulating a number of cellular genes involved in NF- $\kappa \mathrm{B}$ pathway, multiple-drug resistance, cell cycle progression, apoptosis, and genetic stability [7-10]. However, the impact of HBx expression on the therapeutic efficacy of targeted therapy against to receptor tyrosine kinase (RTK) remains unknown. 
Recent understanding of the complex signaling network involved in HCC proliferation, progression and survival leads to the development of sorafenib to this disease [11, 12]. Sorafenib targets several key signal transduction pathways, oncogenes, growth factors and their receptors, including vascular endothelial growth factor (VEGF)/VEGF receptor (VEGFR), platelet-derived growth factor (PDGF)/PDGF receptor (PDGFR), and their downstream Raf kinase. Activation or expression of these molecules has been implicated in resistance to apoptosis, cell proliferation, stimulation of angiogenesis, invasiveness and metastasis of HCC [13-15] and is also correlated with its poor prognosis $[16,17]$. In addition to inducing cell death and inhibiting angiogenesis through targeting VEGFR and PDGFR in a Raf-dependent manner [18], sorafenib also suppresses tumor growth by down-regulation of Mcl-1 and enhancement of ER stress in a Raf-independent manner [19]. However, loss of therapeutic efficacy occurs ultimately despite the initial responses to sorafenib [20-22]. Activation of JAK/STAT, $\mathrm{NF}-\kappa \mathrm{B}$, and PI3K/Akt pathway [23-25], overexpression of HIF- $1 \alpha$ and EGFR $[26,27]$, and induction of EMT and autophagy $[28,29]$ have been proposed to confer the acquired resistance to sorafenib.

In addition to VEGFR, overexpression of ErbB family including EGFR, ErbB2, and ErbB3 also associate with HCC formation [30]. EGFR is activated by binding of its specific ligands and stimulates its downstream PI3K/Akt and Ras/Raf/MEK/MAPK signaling pathway activation, leading to cell proliferation, cell survival, metastasis, and angiogenesis [31, 32]. Therefore, its overexpression is a negative prognostic factor for HCC [33]. Targeting EGFR tyrosine kinase activity by pharmacological inhibitors such as erlotinib and gefitinib are approved for lung cancer. Lapatinib, an EGFR/ErbB2 dual inhibitor, is used for advanced ErbB2-positive breast cancer cells [34-36]. However, the response rate of HCC patients to these EGFR tyrosine kinase inhibitors (TKIs) is low, and combination of sorafenib with EGFR TKIs did not provide additional benefit to $\mathrm{HCC}$ patients $[37,38]$.

Previous studies have shown that $\mathrm{HBx}$ activates Ras/Raf/MEK/MAPK signaling pathway by elevation of VEGFR3 to antagonize pro-apoptosis [39]. HBx also has been reported to increase VEGF expression through upregulation of mTOR pathway [40]. Regulations of EGFR and ErbB2 expression by HBx in HCC cell lines were also described in our previous reports [41, 42]. However, it is unclear whether these regulatory effects of HBx on VEGFR, EGFR family, and their downstream signaling further alter the anti-cancer activity of RTK TKIs. In this study, we addressed the impact of $\mathrm{HBx}$ on the cellular sensitivity of HCC cells to sorafenib and EGFR inhibitors, including gefitinib, erlotinib, and lapatinib. Our data showed that HBx overexpression did not alter the cellular sensitivity of HCC cell lines to sorafenib, but unexpectedly enhanced the cell death induced by EGFR family inhibitors through shifting the oncogenic addiction to ErbB2/ErbB3 signaling pathway via enhancing ErbB3 expression. These findings also suggest HBx and ErbB3 as the potential biomarkers for predicting the therapeutic efficacy of EGFR/ErbB2inhibitors in HCC patients.

\section{RESULTS}

\section{Overexpression of $\mathrm{HBx}$ increases the sensitivity of HCC cell lines to EGFR/ErbB2 TKIs}

It has been reported that HBx may cause chemoresistance in HCC cells [43]. Here, we investigated whether $\mathrm{HBx}$ also renders $\mathrm{HCC}$ cells more resistant to RTK TKIs. First, we compared the sensitivity of Hep3B HCC cell line and its HBx-overexpressing stable clone (Hep3Bx) to sorafenib, the standard TKI therapy for advanced HCC in clinic, by measuring the cell viability in MTT assays after treatment for 3 days. However, the inhibition of viability by sorafenib in these two cell lines had no significant difference (Supplementary Figure S1A), suggesting that HBx overexpression may not affect the anti-cancer activity of sorafenib in HCC cells. EGFR overexpression is commonly observed in HCC [30]. By examining the protein levels of EGFR family members in Western blot analysis, our data indicated that the expressions of EGFR, ErbB2, and ErbB3 were generally abundant in various HCC cell lines (Supplementary Figure S1B). Therefore, we then tested the impact of $\mathrm{HBx}$ expression on the cellular sensitivity of HCC cells to EGFR/ErbB2 TKIs. As shown in Figure 1A, the viability of Hep3B cells was decreased by EGFR/ ErbB2 dual inhibitor lapatinib only at high concentration $(3 \mu \mathrm{M})$, and was not affected completely by two EGFRspecific TKIs, erlotinib and gefitinib. Unexpectedly, HBxoverexpressing Hep3Bx cell line is much more sensitive to these drugs in comparison to its parental cell line. These results suggested that although ErbB family is commonly overexpressed in $\mathrm{HCC}$ cells, it might not be the major driver gene for tumor survival. Nevertheless, when $\mathrm{HBx}$ protein is overexpressed, the addicted pro-survival pathways in HCC cells may be modulated and switched to the ErbB family signaling, leading to the increase of sensitivity to EGFR/ErbB2 TKIs. Because lapatinib showed more obviously inhibitory effect on the viability of Hep3Bx cells than erlotinib and gefitinib did, we focus on lapatinib in the following experiments to address the underlying mechanisms.

To exclude the possibility that the increased sensitivity of $\mathrm{HBx}$-overexpressing stable clone to lapatinib is due to the clonal effect, we transiently transfected myctagged HBx into Hep3B cells followed by treatment with lapatinib for 3 days in the clonogenic assay. The data showed that cell number of $\mathrm{HBx}$-expressing cells was less than that of control cells in response to lapatinib treatment (Figure 1B, upper panel). After crystal violet staining, 
A
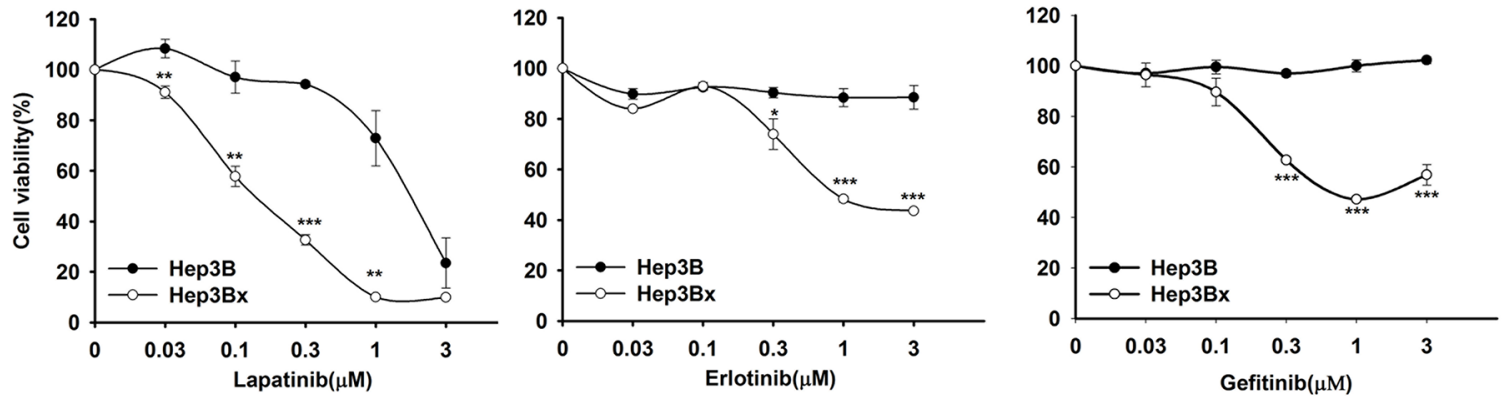

B

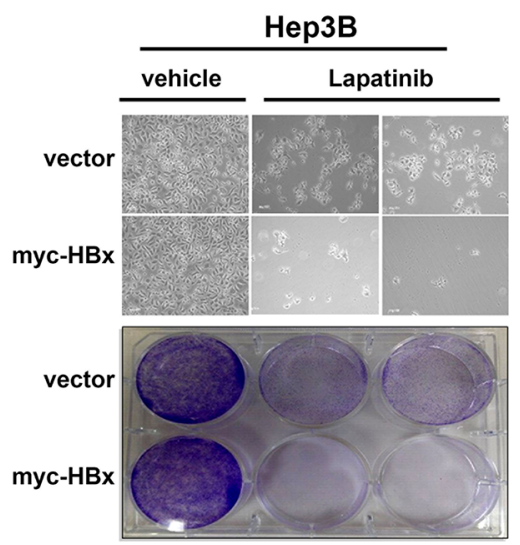

D

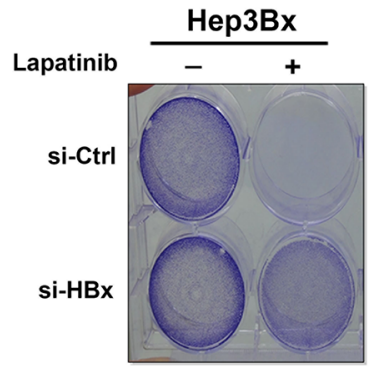

C

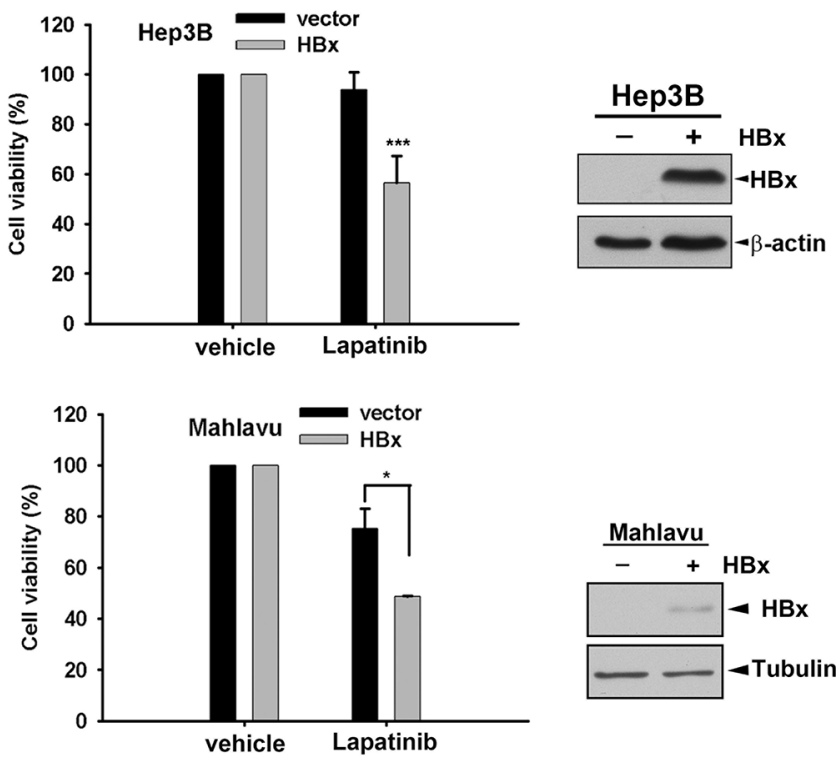

E

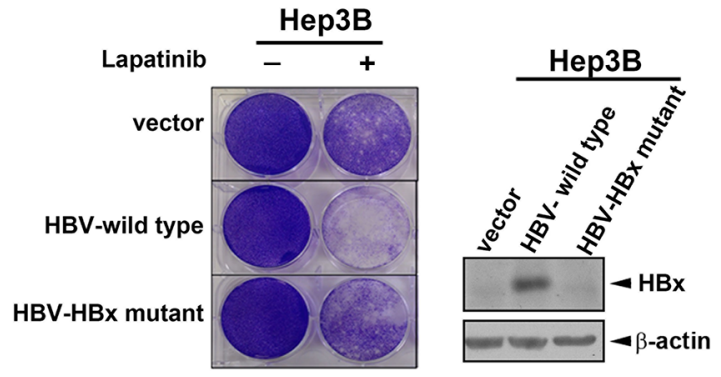

Figure 1: HBx overexpression sensitizes HCC cell lines to EGFR/ErbB2 TKIs. A. The cell viability of Hep3B and Hep3Bx were determined by MTT assay after treatment with lapatinib, erlotinib, and gefitinib for 3 days. B. Hep3B cells were transiently transfected with myc-HBx followed by treatment with $1 \mu \mathrm{M}$ lapatinib for 3 days. The cell viability was determined by crystal violet staining. C. Hep3B and Mahlavu cells were infected by lentivirus and treatment with $0.5 \mu \mathrm{M}$ lapatinib for 3 days. The cell viability was determined by MTT assay. The protein expression of pDEST-HBx and $\beta$-actin was determined by Western blot. $\beta$-actin acts as an internal control. D. Hep3Bx cells were transfected with control and HBx siRNA for 3 days followed by treatment with $1 \mu \mathrm{M}$ lapatinib. The cell viability was determined by crystal violet staining. The protein expression of $\mathrm{HBx}$ and $\beta$-actin was determined by Western blot. E. The control vector, HBV whole genome, and HBx-deleted HBV mutant were transiently transfected into Hep3B cells. After treatment with $1 \mu \mathrm{M}$ lapatinib, the cell viability was detected by crystal violet staining. The protein expression of $\mathrm{HBx}$ and $\beta$-actin was determined by Western blot. Statistical analysis was performed by Student's $t$ test. *, $p<0.05 ;{ }^{* *}, p<0.01 ;{ }^{* * *}, p<0.001$ as compared to control group. 
we can also observe higher sensitivity to lapatinib in HBx-expressing cells than in the control cells (Figure 1B, lower panel). Similar sensitization to lapatinib by lentivirally expressing HBx in Hep3B cells was obtained in MTT assay (Figure 1C, upper). We also tested whether $\mathrm{HBx}$ displays the same function in other HCC cell lines. Mahlavu and HepG2 cells were transiently transfected with HBx followed by lapatinib treatment in MTT assay. Similarly, HBx overexpression also increased lapatinib sensitivity in Mahlavu and HepG2 cells (Figure 1C, lower and Supplementary Figure S1C), suggesting a common lapatinib-sensitizing effect of $\mathrm{HBx}$ in $\mathrm{HCC}$ cells. To further confirm the essential role of $\mathrm{HBx}$ in sensitizing HCC cells to lapatinib, HBx was knocked down by siRNA in Hep3Bx cells in clonogenic assay and the data showed that silencing of $\mathrm{HBx}$ reduced the sensitization to lapatinib in Hep3Bx cells (Figure 1D). Furthermore, Hep3B cells transfected with HBV whole genome also showed higher sensitivity to lapatinib in clonogenic assays, but this effect was abolished when HBx was mutated (Figure 1E), supporting the enhancing effect of $\mathrm{HBx}$ on the anticancer activity of lapatinib in $\mathrm{HCC}$ cells.

We next investigated how $\mathrm{HBx}$ enhanced the anticancer activity of lapatinib in HCC cells. As shown in Figure 2A, the cell death induced by lapatinib was higher in Hep3Bx cells than their parental cells in cell counting assays. Consistently, the induction of sub-G1 population by lapatinib was much more in Hep3Bx cells than in Hep3B cells (Figure 2B). Hep3Bx cells treated with lapatinib followed by double staining with annexin $\mathrm{V} / \mathrm{PI}$ in flow cytometry analysis showed more apoptotic population than Hep3B cells did (Figure 2C), indicating that $\mathrm{HBx}$ overexpression may enhance the pro-apoptotic effect of lapatinib. In supporting to this notion, treatment with lapatinib for 24 hours not only suppressed Akt and ERK activity but also induced more protein cleavage of PARP and Caspase 3 in Hep3Bx cells than in Hep3B cells (Figure 2D). Taken together, these data showed that HBx sensitized HCC cell lines to lapatinib-induced apoptosis.

\section{HBx increases the protein and mRNA levels of ErbB3}

Since lapatinib is an EGFR/ErbB2 dual inhibitor, we next addressed whether $\mathrm{HBx}$ regulates ErbB family expression to sensitize HCC cells to lapatinib. By comparing the ErbB family protein expression and phosphorylation in HBx-overexpressing Hep3Bx and HepG2x and that in their parental cells, our data indicated that HBx decreased EGFR total protein expression but slightly increased phospho-EGFR Tyr992 phosphorylation in Hep3Bx but not in HepG2x cells. In contrast to the inconsistent effect on EGFR phosphorylation, HBx can increase ErbB2 and ErbB3 protein expressions as well as their tyrosine phosphorylation in both Hep3Bx and HepG2x cells. The ErbB2/ErbB3 downstream Akt signaling is also higher in Hep3Bx and HepG2x cells than in their parental cells (Figure 3A). We also analyzed the mRNA level of ErbB family in Hep3B and Hep3Bx cells by using RT-qPCR analysis. We found that mRNA expression of ErbB3 was dramatically higher in Hep3Bx cells than in Hep3B cells (Figure 3B).

Both $\mathrm{HBx}$ and ErbB3 have been reported to be capable of inducing Akt activation [44, 45]. The expression of ErbB3 was directly correlated with the degree of sensitivity of breast cancer cell lines to lapatinib [46]. Hence, we suggested that $\mathrm{HBx}$ might contribute to lapatinib sensitization through up-regulation of ErbB3 and the subsequent activation of ErbB2/Akt axis. To this end, we first transiently transfected Hep3B and HepG2 cells with HBx followed by Western blot and RT-qPCR analyses. As shown in Figure $3 \mathrm{C}$ and $3 \mathrm{D}$, ErbB3 protein and mRNA expression were both induced by $\mathrm{HBx}$ in Hep3B and HepG2 cells. Consistently, ErbB3 protein level in Hep3B cells was also induced by HBV whole genome, and this induction was abolished when $\mathrm{HBx}$ was mutated (Figure 3E). Moreover, silencing of $\mathrm{HBx}$ by siRNA decreased the expression of ErbB3 in both mRNA and protein in Hep3Bx cells (Figure 3F). We then examined the correlation between ErbB3 induction and $\mathrm{HBV}$ infection in clinical HCC specimens. The mRNA level of ErbB3 is higher in HBV-associated HCC group in comparison to that in non-virus infection HCC (NBNC) group (Figure 3G). ErbB3 protein expression was also higher in HBV-associated tumor tissues than in their adjacent normal tissues (Figure $3 \mathrm{H}$ ). In addition, positive correlation between $\mathrm{HBx}$ and ErbB3 protein expressions in these HBV-associated tumor tissues was also obtained (Figure 3I). Taken together, these results indicated that ErbB3 is specifically up-regulated by HBx in HCC cells.

\section{ErbB3 overexpression enhances the sensitization of $\mathrm{HCC}$ cell lines to lapatinib}

Next, we addressed whether the increased ErbB3 expression is sufficient for the sensitization of HCC cells to lapatinib. As shown in Figure 4A, viability of Hep3B cells expressing DsRed-ErbB3 fusion protein but not DsRed alone were suppressed by lapatinib. In clonogenic assays, the inhibitory effect of lapatinib on the viability of Hep3B cell was also observed obviously after transfection with ErbB3 (Figure 4B). Moreover, silence of ErbB3 by shRNA not only reduced the viability of Hep3Bx cells in MTT assay (Figure 4C), but also synergized the inhibitory effect of lapatinib in clonogenic assays (Figure 4D). However, ErbB3 shRNA did not affect the survival of Hep3B cells (Figure 4C). These findings suggest that HBx renders HCC cells addicted to ErbB3 signaling. In supporting to this finding, silencing of ErbB3 reduced Akt activity and enhanced the lapatinib-induced Caspase3 cleavage in Hep3Bx cells (Figure 4E), indicating the dominance of the pro-survival and anti-apoptotic signaling by HBx-induced ErbB3 in HCC cells. Indeed, lapatinibinduced sub-G1 population was further enhanced by 
silence of ErbB3 with siRNA in Hep3Bx cells (Figure 4F). Taken together, our data indicated that HBx sensitizes $\mathrm{HCC}$ cells to lapatinib through up-regulation of ErbB3 expression.

\section{Overexpression of $\mathrm{HBx}$ enhanced the dimerization of ErbB2 and ErbB3}

ErbB3 does not possess tyrosine kinase activity and drives downstream signaling through heteromeric association with other ErbB family members [47-49]. Since ErbB3 expression is up-regulated in accompany with the kinase activation of ErbB2 but not EGFR and ErbB4 in response to HBx overexpression (Figure 3A), hence we further investigated whether HBx promotes the up-regulated ErbB3 to form a activated complex with ErbB2. First, we examined the correlation between ErbB2 and ErbB3 in various HCC cell lines, and positive correlation between ErbB3 and ErbB2 protein levels was found (Figure 5A). Ectopic expression of ErbB3 in Hep3B
A

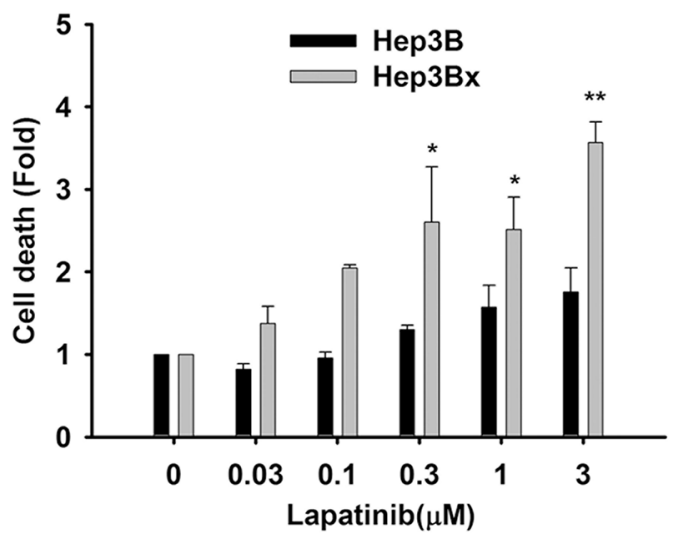

C

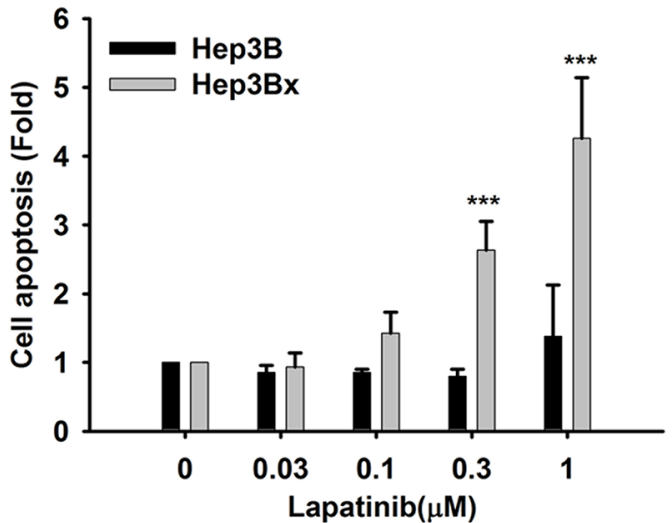

B

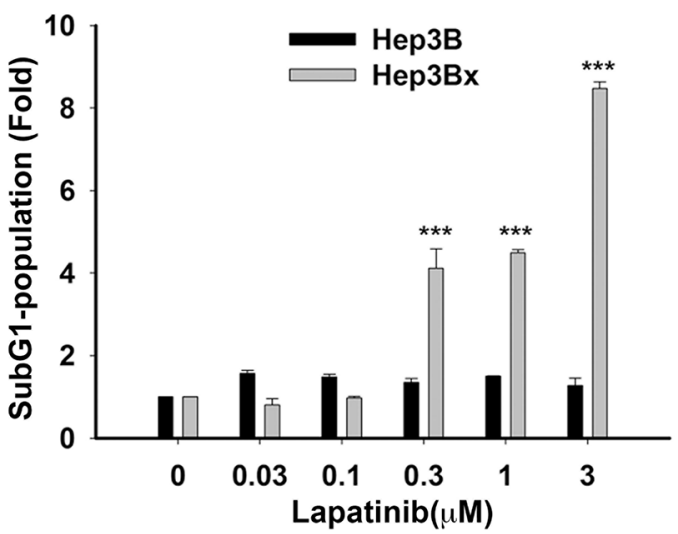

D

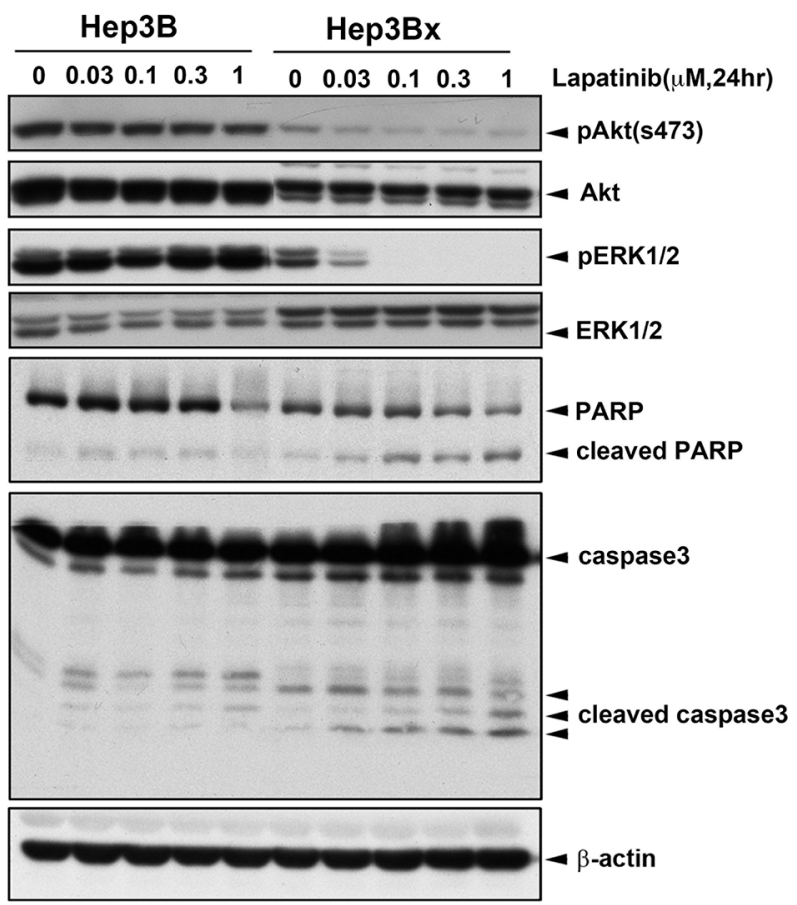

Figure 2: HBx enhanced the sensitization of Hep3B cells to lapatinib-induced apoptosis. A-C. Hep3B and Hep3Bx were treated with indicated concentration of lapatinib for 5 days. The cells were trypsinized for cell number counting (A), PI staining for determining sub-G1 population (B), and PI and Annexin V double staining for determining apoptosis (C). D. Total lysate prepared from lapatinib-treated Hep3B and Hep3Bx cells were subjected to Western blot analysis with anti-pAkt(s473), anti-Akt, anti-pERK, anti-ERK, anti-PARP, anti-caspase3, and anti- $\beta$-actin antibodies. Statistical analysis was performed by Student's $t$ test. *, $p<0.05$; **, $p<0.01 ; * * *$, $p<0.001$ as compared to control group. 
A

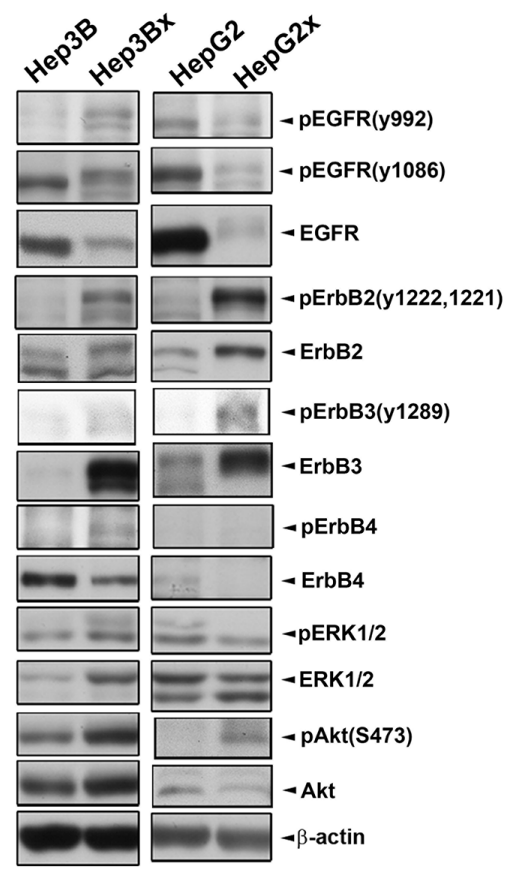

B

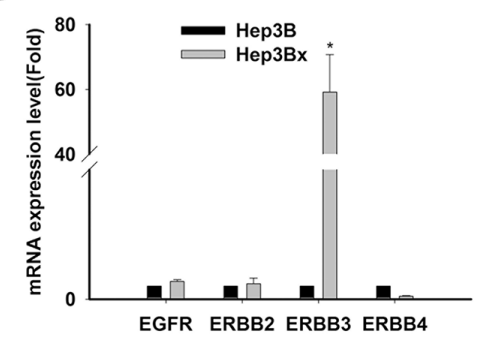

C
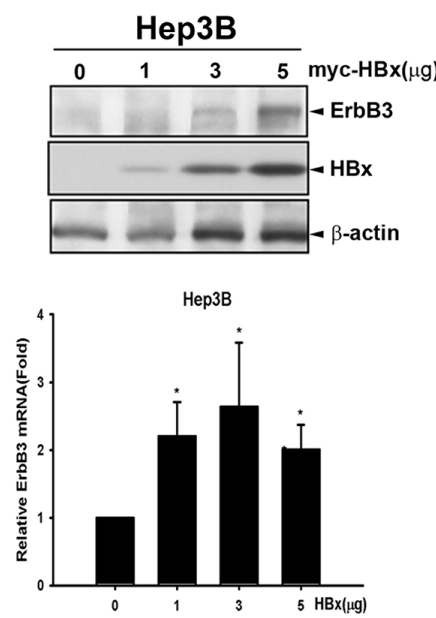

D
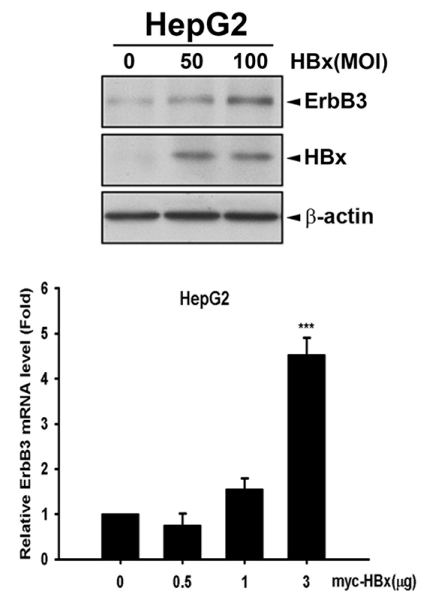

E

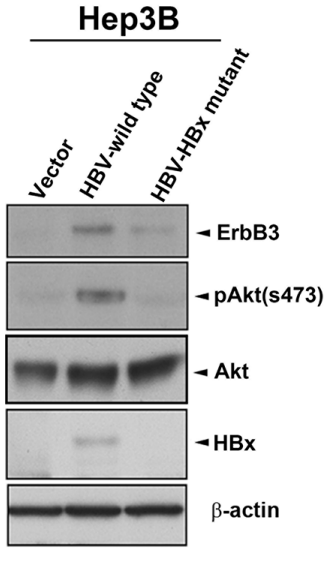

F
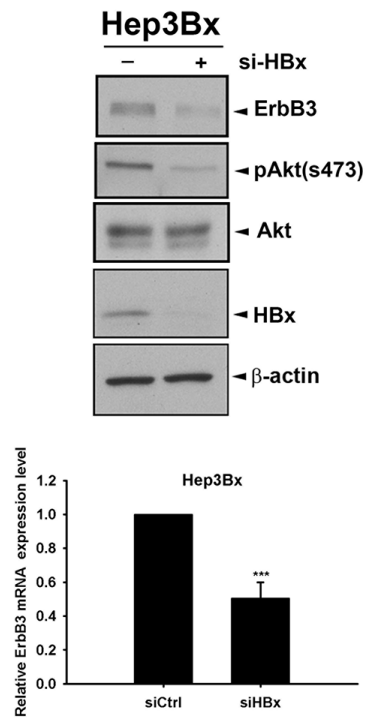

G

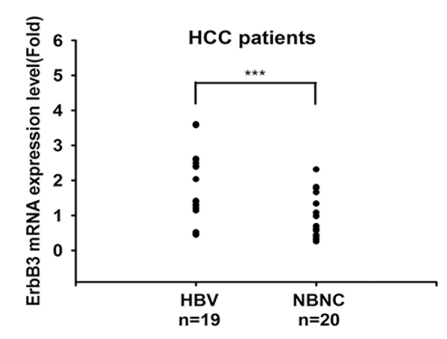

H

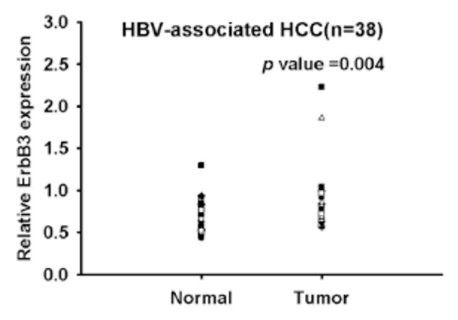

I

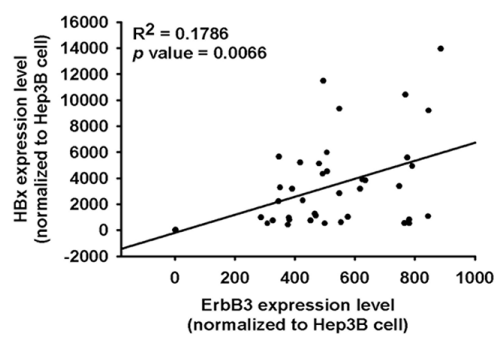

Figure 3: HBx up-regulates ErbB3 expression at both mRNA and protein levels. A. The expression of ErbB family and downstream signaling in Hep3B and HepG2 cells and their HBx-derivatives were determined by Western blot. B. The mRNA expression of ErbB family in Hep3B and Hep3Bx cells were examined by RT-qPCR analysis. The mRNA levels of ErbB family were normalized to GAPDH expression. C-D. Hep3B and HepG2 cells were transiently transfected or infected with HBx at different dose for 2 days. The protein expression and mRNA level of ErbB3 were detected by Western blot and RT-qPCR analysis, respectively. E-F. Hep3B cells were transfected with control vector, HBV-whole genome, and HBx-deleted HBV mutant for 2 days (E) Hep3Bx cells were transiently transfected with si-HBx for 3 days (F) The protein expression and mRNA level of ErbB3 were detected by Western blot and RT-qPCR analysis, respectively. G. The ErbB3 mRNA level of HCC patients were examined by RT-qPCR. The fold changes of ErbB3 mRNA were normalized to its adjacent normal tissue. H. The protein expression level of ErbB3 examined by Western blot and quantified by image J system. The expression level of ErbB3 was normalized to $\beta$-actin. I. Total lysates from HBV-associated HCC tumor liver tissue were prepared and subjected to Western blot with anti-ErbB3, HBx and ERK antibodies. The coefficient of determination $\left(\mathrm{R}^{2}\right)$ between ErbB3 and HBx expression level was analyzed by simple regression, $p<0.001$. 
A

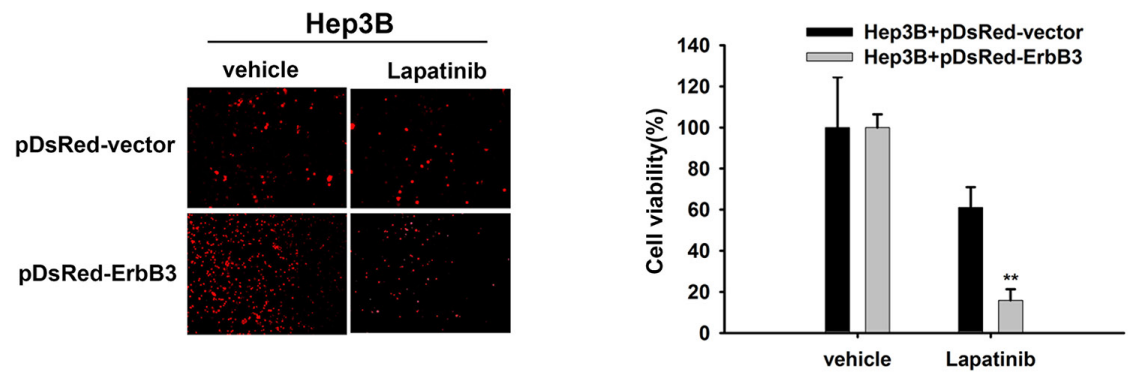

B

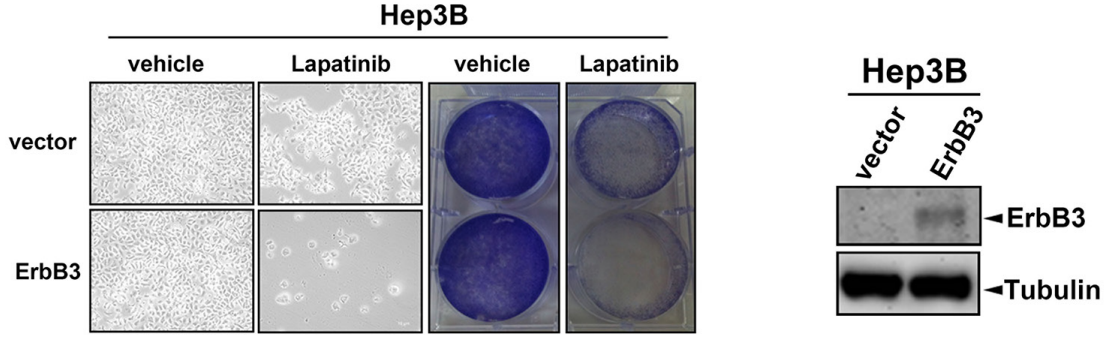

C

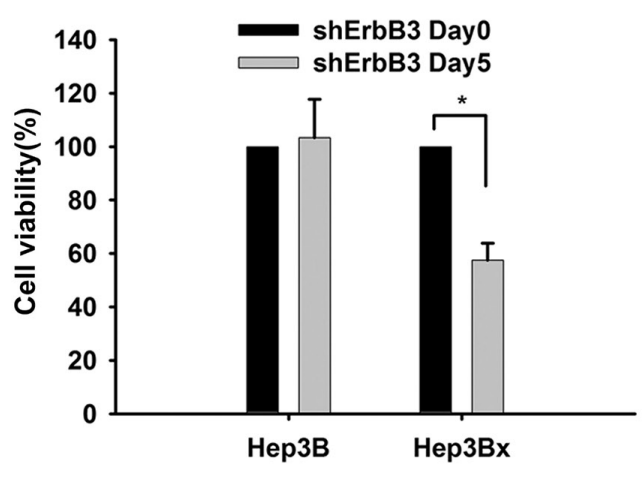

D

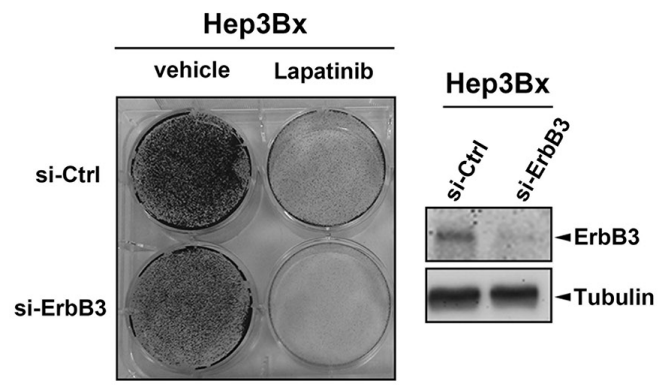

E

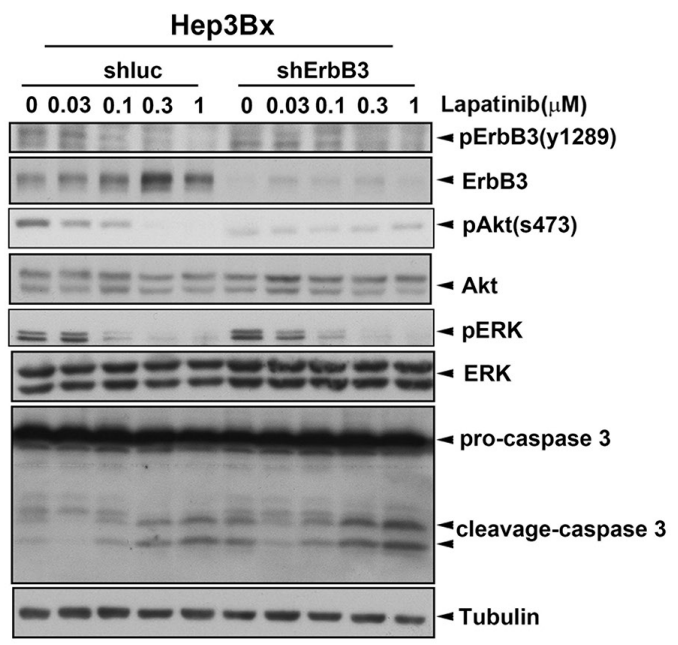

$\mathbf{F}$

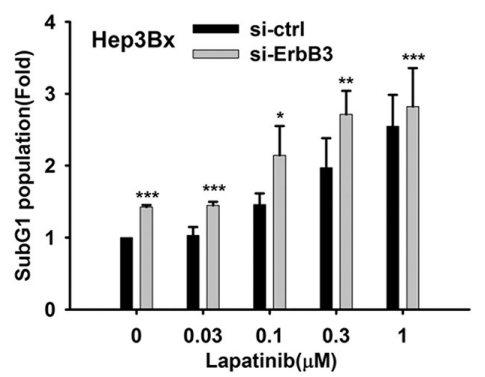

Figure 4: Overexpression of ErbB3 sensitized Hep3B cells to lapatinib. A. Hep3B cells were transiently transfected with pDsRed vector or pDsred-conjugated ErbB3 for 24 hours followed by $1 \mu \mathrm{M}$ lapatinib treatment for 5 days. The red fluorescence was detected by fluorescence microscope. B. Hep3B cells were transiently transfected with vector control or ErbB3 followed by lapatinib treatment. The cell viability was determined by crystal violet staining. The protein expression of ErbB3 and internal control-Tubulin were detected by Western blot. C. Hep3B and Hep3Bx were infected with shErbB3 for 5 days. The cell viability was determined by MTT assay. D. Hep3Bx cells were transfected with control or ErbB3 siRNA for 5 days followed by lapatinib treatment. The cell survival was detected by crystal violet staining. The protein expression of ErbB3 and internal control-Tubulin were determined by Western blot. E. Hep3Bx cells were infected with luc shRNA and ErbB3 shRNA for 5 days followed by treatment with lapatinib for 24 hours. The protein expression was detected by Western blot. F. Hep3Bx cells were transfected with control or ErbB3 siRNA followed by lapatinib treatment for 5 days. The sub-G1 population was determined by PI staining in flow cytometry analysis. Statistical analysis was performed by Student's $t$ test. *, $p<$ $0.05 ; * *, p<0.01 ; * * *, p<0.001$ as compared to control group. 
A

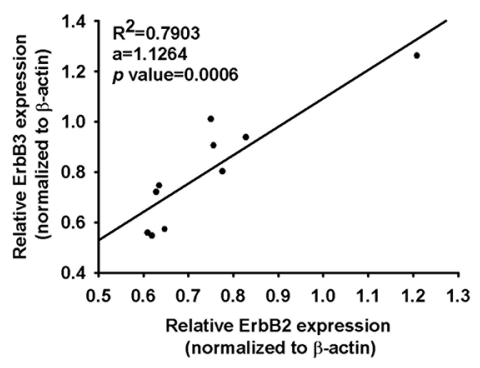

E
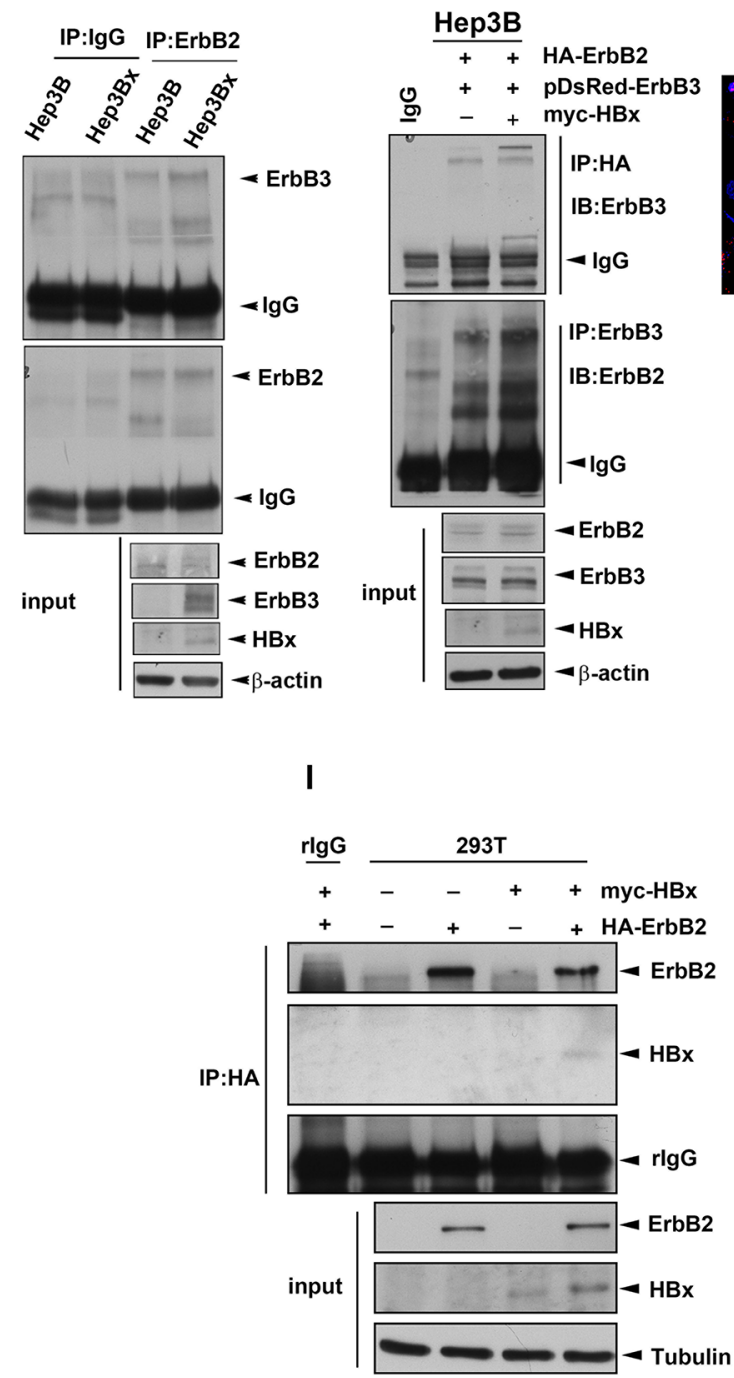

C

D

Hep3B

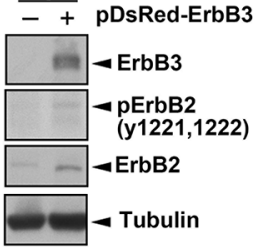

G

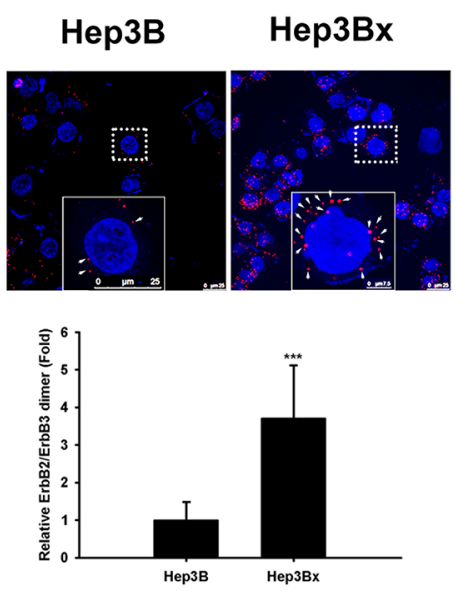

H

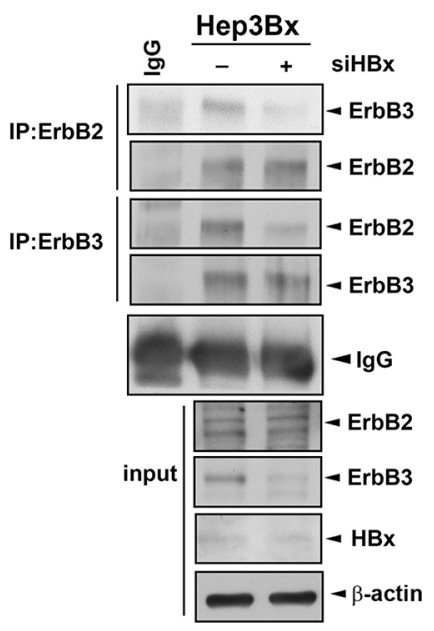

$\mathbf{J}$

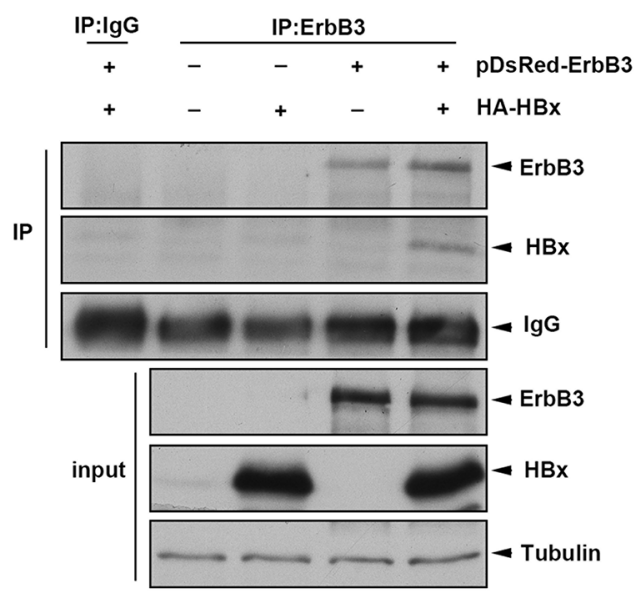

Figure 5: Overexpression of HBx enhanced the dimerization of ErbB2 and ErbB3. A. The protein expression in human HCC cell lines was examined by Western blot and quantified by image J system. The expression level of ErbB2 and ErbB3 were normalized to its $\beta$-actin. The coefficient of determination $\left(\mathrm{R}^{2}\right)$ between ErbB3 and ErbB2 expression level was analyzed by simple regression, $p<$ 0.001. B. Hep3B cells were transfected with DsRed vector or DsRed fused ErbB3. The protein expression was determined by Western blot. C. Hep3Bx cells were infected with shRNA, the protein expression was determined by Western blot. D. Hep3Bx cells were infected with shRNA and transfected with HA-ErbB2 for 2days. The protein expression was determined by Western blot. E. Total lysate prepared from Hep3B and Hep3Bx cells were subjected to IP/Western blot analysis. F, I. and J. Hep3B (F) or HEK293T (I and J) cells were transient transfected with ErbB2, ErbB3, and vector or HBx, respectively. The total lysates were harvested for IP/Western blot with indicated antibodies. G. Hep3B and Hep3Bx were seeded for 24 hour and detected the interaction of ErbB3 and ErbB2 by using PLA kit. The red fluorescence was detected by confocal microscope. H. Hep3Bx cells were transfected with control or ErbB3 siRNA for 3 days. The total lysates were harvested for IP/ Western blot with indicated antibodies. 
cell also increased the protein and tyrosine kinase activity of ErbB2 (Figure 5B). On the contrary, silencing ErbB3 by shRNA reduced ErbB2 protein and tyrosine kinase activity expression (Figure 5C). In addition, silence of ErbB3 by shRNA specifically targeting its 3'UTR also decreased ectopic expression of ErbB2, indicating that ErbB3 affects the stability of ErbB2 at post-transcriptional level (Figure 5D).

ErbB3 prefers to form heteromeric protein complex with ErbB2 [48]. Here, we further investigate whether overexpression of $\mathrm{HBx}$ enhanced the interaction between ErbB2 and ErbB3 in IP/WB analysis, and the results showed that the co-immunoprecipitated ErbB3 in the antiErbB2 immunocomplex was more abundant in Hep3Bx cells than in Hep3B cells (Figure 5E). Furthermore, overexpression of $\mathrm{HBx}$ can increase the interaction between ectopically expressed ErbB2 and ErbB3 protein in the reciprocal IP/WB analysis (Figure 5F). In proximity ligation assay (PLA), the ErbB2/ErbB3 protein interaction (red spot) was not only located on the plasma membrane but also was more abundant in Hep3Bx cells than in Hep3B cells (Figure 5G). In contrast, silence of HBx by siRNA significantly decreased the interaction between these two receptors in Hep3Bx cells (Figure $5 \mathrm{H})$. We further examined whether $\mathrm{HBx}$ physically interacts with ErbB2 and ErbB3 by co-transfection of HBx with ErbB2 or ErbB3 into HEK293T cell, and found that $\mathrm{HBx}$ can be detected in the anti-ErbB2 and anti-ErbB3 immunoprecipitates (Figure 5I and 5J). These results indicated that $\mathrm{HBx}$ protein enhances the ErbB2/ ErbB3 complex formation by physically protein-protein interaction with both of them.

\section{HBx induced ErbB3 expression through enhancing ErbB3 promoter activity}

Next, we investigated whether HBx transcriptionally up-regulates ErbB3 expression through enhancing its promoter activity. HEK293T cells were co-transfected with $\mathrm{HBx}$ and the luciferase construct containing the essential regulatory region of $E r b B 3$ promoter [50]. As shown in Figure 6A, the $E r b B 3$ promoter activity was increased in $\mathrm{HBx}$-expressing cells in a dose-dependent manner, indicating that $\mathrm{HBx}$ transcriptionally increased ErbB3 gene expression. $\mathrm{HBx}$ has been reported to activate various transcription factors such as AP-1, NF- $\kappa B$, and CREB [51-53]. By using JASPAR database, the putative transcription factors binding to $E r b B 3$ promoter were predicted (Figure 6B), and among them Sp-1, NF- $\kappa \mathrm{B}$, AP1, E2F1, and HNF4 $\alpha$ have been reported to be activated in response to $\mathrm{HBx}$ expression [54-58]. After screening with the inhibitors of these transcription factors, ErbB3 expression was dramatically decreased by pyrrolidine dithiocarbamate (PDTC) and mithramycin A, specific inhibitors against $\mathrm{NF}-\kappa \mathrm{B}$ and $\mathrm{Sp} 1$ respectively (Figure $6 \mathrm{C})$. Overexpression of $\mathrm{p} 65$ but not $\mathrm{Sp}-1$ enhanced both ErbB3 mRNA and protein levels (Figure 6D and data not shown). In addition to activating NF- $\kappa \mathrm{B}$ through phosphorylation of I $\kappa$ B in the cytoplasm [59], IKK $\alpha$ has been reported to function as a epigenetic regulator for NF$\kappa \mathrm{B}$-dependent gene transcription in the nucleus in response to $\mathrm{HBx}$ overexpression $[42,60]$. Our result showed that overexpression of IKK $\alpha$ can induce ErbB3 expression at both mRNA and protein levels in a dose-dependent manner (Figure 6E). In contrast, silencing of p65 by shRNA reduced both ErbB3 mRNA and protein expressions (Figure 6F). Moreover, silence of IKK $\alpha$ also suppressed ErbB3 protein level in Hep3Bx cells (Figure 6G). It has been reported that IKK $\beta$, another subunit of IKK complex, activates p65 activity through phosphorylation of $\mathrm{I} \kappa \mathrm{B} \alpha$. Here we also determined whether IKK $\beta$ also involved in ErbB3 up-regulation. Silence of IKK $\beta$ by using shRNA obviously suppressed ErbB3 expression (Supplementary Figure S2B). On the contrary, overexpression of IKK $\beta$ increased ErbB3 expression (Supplementary Figure S2C). These data suggest that IKK/NF- $\kappa \mathrm{B}$ is involved in $\mathrm{HBx}-$ mediated ErbB3 expression.

By using JASPAR database, there are three predicted p65-binding sites ( $\kappa \mathrm{B} 1:-1242$ to $-1229 ; \kappa \mathrm{B} 2$ -1117 to -1103 ; $\kappa B 3-1013$ to -1004$)$ on $E r b B 3$ promoter. Our results found that mutation of $\kappa \mathrm{B} 2$ or $\kappa \mathrm{B} 3$ but not $\kappa \mathrm{B} 1$ significantly decreased $E r b B 3$ promoter activity (Figure 7A). Overexpression of p65 but not Sp1 enhanced $E r b B 3$ promoter activity in a dose-dependent manner in HEK293T cells (Figure 7B). In contrast, silence of $\mathrm{p} 65$ by two different clones of shRNA decreased $E r b B 3$ promoter activity in Hep3Bx cells (Figure 7C). Furthermore, treatment with PDTC and BAY-11-7802 to respectively inhibit NF- $\kappa$ B and IKK $\alpha$ activation in Hep3Bx cells also suppressed ErbB3 promoter activity (Figure 7D and 7E). To further demonstrate that ErbB3 expression was transcriptionally regulated by $\mathrm{NF}-\kappa \mathrm{B}$ in vivo, the binding activity of p65 on $E r b B 3$ promoter was determined in ChIP assays, and the results showed that the association of p65 to the ErbB3 promoter was obviously higher in $\mathrm{HBx}$-overexpressing Hep3Bx cells than in Hep3B cells (Figure 7F). These data suggest that NF- $\kappa \mathrm{B}$ directly binds to $\operatorname{ErbB} 3$ promoter and regulates ErbB3 expression in response to $\mathrm{HBx}$ expression.

\section{DISCUSSION}

EGFR inhibitors such as erlotinib, lapatinib, and cetuximab alone or in combination with sorafenib have been tested for HCC treatment [61], but did not provide additional benefit to these patients [62]. EGFR mutation or ErbB2 overexpression has been viewed as critical biomarkers for treatment of EGFR TKIs in NSCLC and breast cancer patients [34]. However, such mutations were not found in $\mathrm{HBx}$-expressing $\mathrm{HCC}$ cells, and also were not associated with the therapeutic efficacy of EGFR TKIs in HCC patients $[63,64]$. Our data unexpectedly found that $\mathrm{HBx}$ can sensitize HCC cell lines to EGFR/ ErbB2 TKIs, including lapatinib, erlotinib, and gefitinib, 
A

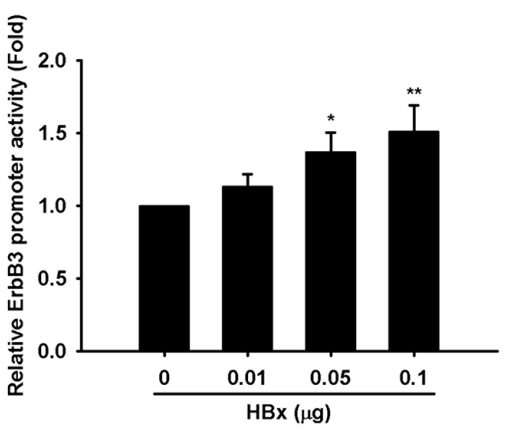

D

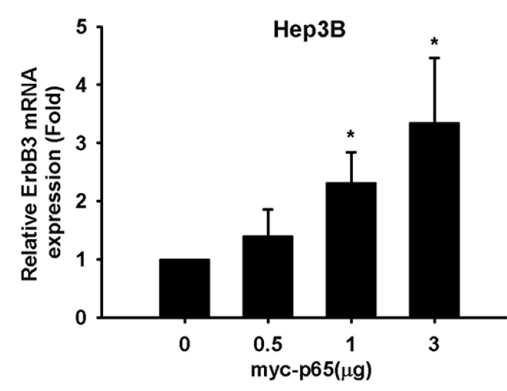

Hep3B

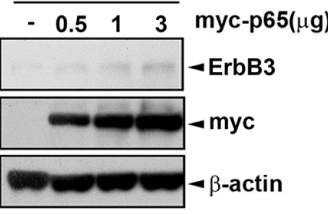

F

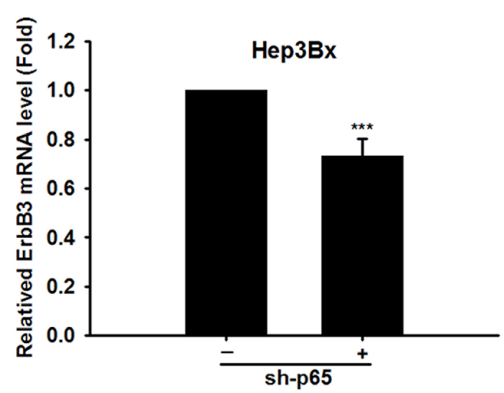

Hep3Bx

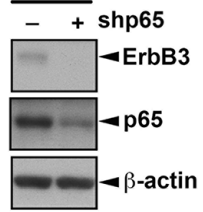

B

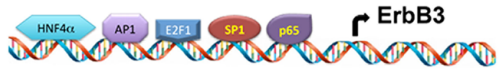

C

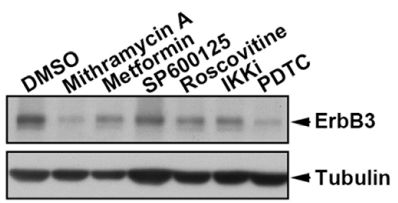

E

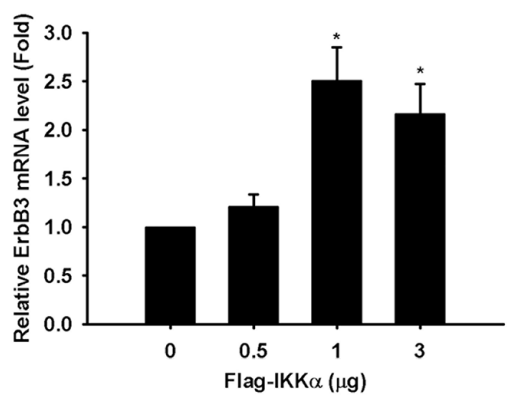

Hер3B

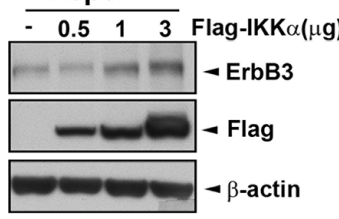

G

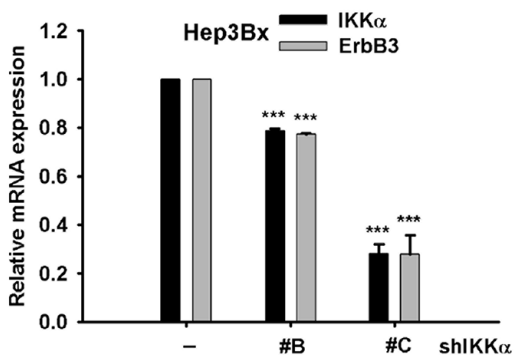

Hep3Bx

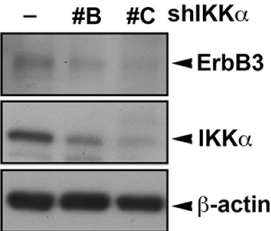

Figure 6: $\boldsymbol{\alpha} / \mathrm{NF}-\boldsymbol{\kappa B}$ HBx mediates HBx-induced ErbB3 transcription. A. HEK293T cells were transfected with indicated concentration of $\mathrm{HBx}$, promoter control or ErbB3 promoter-luciferase, respectively. The culture medium was prepared for detecting promoter activity and the total lysates were harvested for renilla activity. B. The putative transcription factor for ErbB3 promoter was illustrated. C. Hep3Bx cells were treated with Mithramycin A $0.3 \mu \mathrm{M}$, Metformin $5 \mathrm{mM}$, SP600125 $30 \mu \mathrm{M}$, Roscovitine $20 \mu \mathrm{M}$, IKKi 10 $\mu \mathrm{M}$, and PDTC $10 \mu \mathrm{M}$ for $24 \mathrm{hr}$. D-G. Hep3B cells were transfected with myc-p65 or Sp-1 in different dose for $48 \mathrm{hr}$ (D) Hep3B cells were transfected with indicated dose of Flag-IKK $\alpha$ for $48 \mathrm{hr}$ (E) Hep3Bx cells were infected with p65 shRNA for 3 days (F) Hep3Bx cells were infected with three different clones of IKK $\alpha$ shRNA for 3 days $(\mathrm{G})$ The ErbB3 mRNA and protein expression level were examined by RT-qPCR and Western blot. Statistical analysis was performed by Student's $t$ test. *, $p<0.05 ; * *, p<0.01$; ***, $p<0.001$ as compared to control group. 
A

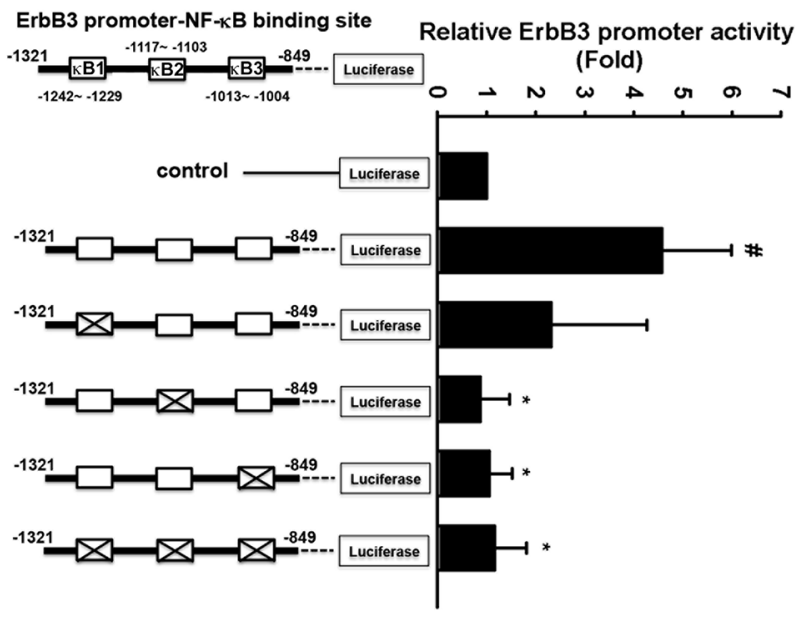

B

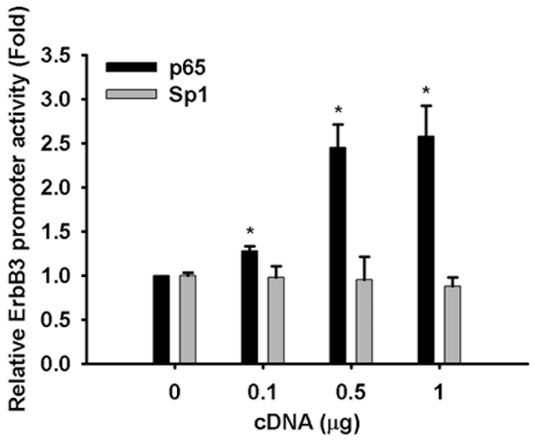

$\mathbf{E}$

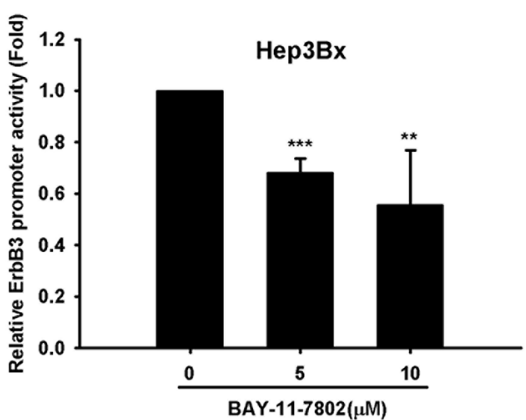

$\mathbf{F}$

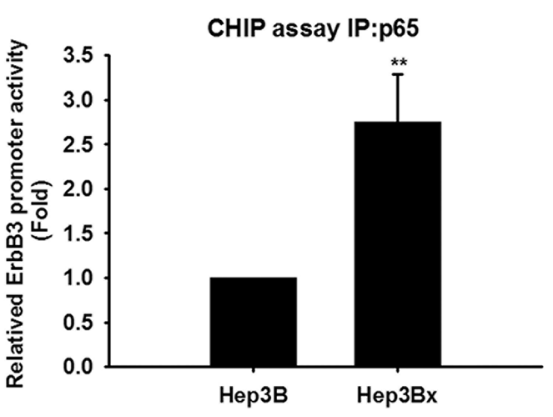

D

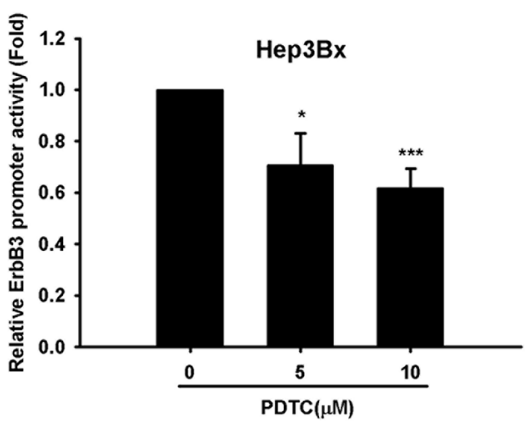

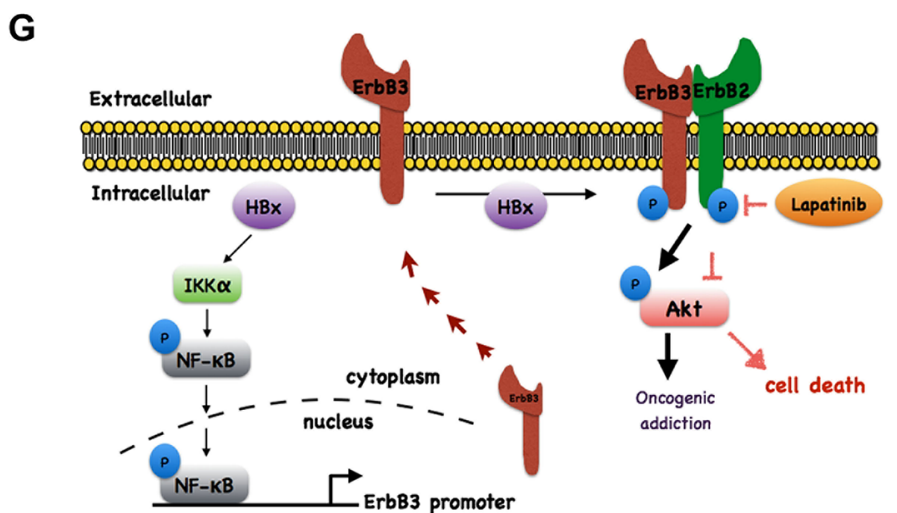

Figure 7: NF-אB directly binds to and up-regulates ErbB3 promoter. A-E. HEK293T cells were transfected with, control or ErbB3 promoter-luciferase with or without mutations at putative $\kappa B$ binding sites 1, 2, and 3 (A) HEK293T cells were transfected with control or ErbB3 promoter-luciferase and indicated doses of myc-p65 or Sp-1 (B) Hep3Bx cells were transduced with p65 shRNA (C) or were treated with PDTC (D) or BAY-11-7802 (E) for $48 \mathrm{hr}$ after transfection with ErbB3 promoter-luciferase. The culture medium was prepared for detecting promoter activity and the total lysates were harvested for renilla activity. F. Total lysate of Hep3B and Hep3Bx were harvested for chromatin IP analysis with anti-p65 antibody, and the binding activity of p65 on ErBb3 promoter was determined by qPCR analysis. Statistical analysis was performed by Student's $t$ test. *, $p<0.05 ;{ }^{*}, p<0.01$ as compared to control group. G. Diagrammatic illustration of the hypothetical model derived from this study. 
and suggest ErbB3 overexpression as a potential biomarker to predict the therapeutic efficacy of lapatinib in HCC patients.

Our data showed that HBx-expressing HCC cells were oncogenically addicted to ErbB3/ErbB2 signaling pathway as evidenced by the findings that silence of ErbB3 and treatment with lapatinib synergistically induced cell death in HBx-expressing cells. Like ErbB3 induction by $\mathrm{HBx}$, ectopic overexpression of ErbB3 also increased the oncogenic addiction of HCC cells to this RTK, and thereby sensitizes HCC cells to lapatinib. Mechanistically, HBx increased ErbB3 protein expression and mRNA level through enhancing its promoter activity, and also augmented the formation of ErbB2/ErbB3 complex through protein-protein interactions with these receptors.

In this study, we identified NF- $\mathrm{KB}$ as the key transcription factor for $E r b B 3$ promoter activation. Although our data also showed that mithramycin A inhibited both $\mathrm{Sp} 1$ and ErbB3 protein expression (Figure 6C), ErbB3 promoter activity was not increased by overexpression of $\mathrm{Sp} 1$ (Figure 7B). Moreover, mithramycin $\mathrm{A}$ has been reported to suppress $\mathrm{Sp} 1$ activity as well as TNF- $\alpha$-induced NF- $\kappa B$ activation [65]. Our data also showed that mithramycin A reduced $\mathrm{p} 65$ activity in Hep3Bx cells (Supplementary Figure S2A). These observations suggest that NF- $\kappa \mathrm{B}$, but not Sp1, plays a critical role in mediating $\mathrm{HBx}$-induced ErbB3 expression. In addition to inducing ErbB3 gene transcription, $\mathrm{HBx}$ also increased the protein expression of DsRed-ErbB3 (Supplementary Figure S3A). Moreover, silencing of HBx in Hep3Bx cells decreased ErbB3 protein stability in the presence of cycloheximide (Supplementary Figure S3B), suggesting the existence of post-translational modification. Our data further demonstrate that $\mathrm{HBx}$ can physically bind to both ErbB3 and ErbB2 to enhance the ErbB3/ErbB2 interaction (Figure 5I and 5J). These results revealed that HBx dually up-regulates ErbB3 at both transcriptional and posttranslational levels, and explain why the augmenting effect of $\mathrm{HBx}$ on ErbB3 promoter activity is not parallel to that on ErbB3 protein expression.

Although HBx-expressing cells are more sensitive to lapatinib, our data also showed that erlotinib and gefitinib did not completely suppress the viability of cells even at high dose. In contrast to the up-regulation of ErbB2 and ErbB3, our data showed that EGFR expression level is decreased by HBx (Figure 3A) probably due to the suppression by HBx-induced miR-7 [42], suggesting possible reason for the incompletely suppressive effect of erlotinib and gefitinib on viability of $\mathrm{HBx}$-expressing cells at high dose.

Several potential reasons could explain why the therapeutic benefits of EGFR/ErbB2 TKIs on HCC patients were not observed in clinical trials. Recruitment of non-HBV-associated HCC patients in the clinical trials would be the first possible reason for the inefficacy of EGFR TKIs [62]. Another plausible reason is that the HBV DNA level or HBsAg expression, which is practically measured in clinic, may not be actually associated with the HBx expression in $\mathrm{HCC}$ tissues. Expression of $\mathrm{HBx}$ is cyclic but not steady when HBV is replicated in HCC cells [66]. It has also been found that $32 \%$ of HBV-associated HCC patients express HBx with C-terminal deletion [67], which reduces the transactivation activity of HBx [68, 69]. Therefore, the dynamic or truncated expression of $\mathrm{HBx}$ in HCC tissues of HBV-positive patients may not be able to induce ErbB3 expression and sensitize HCC cells to lapatinib. These findings indicate the limitation of $\mathrm{HBx}$ as the biomarker to predict the therapeutic efficacy of lapatinib in HCC patients. Although our data showed clinical correlation between $\mathrm{HBx}$ and ErbB3 expressions, this finding should be further validated due to the limited number of human HCC samples used in this study.

In summary, our study indicated that HBx increases ErbB3 expression through IKK $\alpha / \mathrm{NF}-\mathrm{KB}$ signaling pathway and enhances the formation ErbB2/ErbB3 complex by physically protein-protein interaction. This effect thereby shifts the oncogenic addiction of HCC cells to ErbB2/ErbB3 and sensitizes them to lapatinib (Figure $7 \mathrm{E})$. Furthermore, HBx and ErbB3 overexpression could serve as potential biomarkers for predicting therapeutic efficacy of EGFR/ErbB2 inhibitors in HCC patients.

\section{MATERIALS AND METHODS}

\section{Cell lines and cell culture}

Human hepatocellular carcinoma cell lines, Hep3B, HepG2, their derivatives with HBx expression were cultured in Dulbecco's Modified Eagle Medium: Nutrient Mixture F-12 (DMEM/F12) and supplemented with 10\% fetal bovine serum (Gibco), 100U/ml penicillin, and 100U/ $\mathrm{ml}$ streptomycin. SK-Hep1, Tong, Mahlavu, HCC36 were cultured in Dulbecco's Modified Eagle Medium (DMEM) and supplemented with $10 \%$ fetal bovine serum (Gibco), $100 \mathrm{U} / \mathrm{ml}$ penicillin, and $100 \mathrm{U} / \mathrm{ml}$ streptomycin.

Huh7 was cultured in Dulbecco's Modified Eagle Medium (DMEM) with 1\% L-glutamine and supplemented with $10 \%$ fetal bovine serum (Gibco), $100 \mathrm{U} / \mathrm{ml}$ penicillin, and $100 \mathrm{U} / \mathrm{ml}$ streptomycin. HA22T/ VGH was cultured in Dulbecco's Modified Eagle Medium (DMEM) with $1 \%$ L-glutamine, $1 \%$ Non-Essential Amino Acid and supplemented with $10 \%$ fetal bovine serum (Gibco), 100U/ml penicillin, and $100 \mathrm{U} / \mathrm{ml}$ streptomycin. These cells are all incubated at $37^{\circ} \mathrm{C}$ in a humidified atmosphere of $95 \%$ air and $5 \% \mathrm{CO}_{2}$.

\section{Transfection}

Cells were transfected with plasmid or si-RNA by using Lipo-Fectamine 2000 (invitrogen) or TransIT-X2 (Mirus) transfection reagent according to the manufacturer's instruction. After $48 \mathrm{hr}$ of transfection, cells lysates were harvested and subjected to analysis. 
Oligonucleotide used for PCR, mutagenesis, or RNA interference were listed in Supplementary Tables S1-S3.

\section{Preparation of cell lystes}

The cell lysates were extracted in RIPA buffer ( 50 $\mathrm{mM}$ pH7.4 Tris-HCl, $1 \%$ Nonidet P- $40,0.15 \%$ Na-DOC, $150 \mathrm{mM} \mathrm{NaCl}$ and $1 \mathrm{mM}$ EDTA) with protease inhibitors, homogenized with sonication and store at $-30^{\circ} \mathrm{C}$.

\section{Western blot and antibody}

The concentration of protein was measured by Bradford protein assay (Bio-Rad protein assay). Protein was denatured in $1 \mathrm{X}$ sample buffer at $95^{\circ} \mathrm{C}$ for 5 minutes, and separated by SDS-PAGE followed by transfer to a PVDF membrane $(0.45 \mu \mathrm{m}$, millipore) or NC membrane $(0.22 \mu \mathrm{m}$, GE Healthcare). The membrane was blocked with 5\% milk in Tris-Bufferd Saline-Tween (TBST; $10 \mathrm{~mL}$ of $2 \mu \mathrm{M}$ TrisHCL pH7.4, $100 \mathrm{~mL}$ of $5 \mathrm{M} \mathrm{NaCl}, 0.5 \mathrm{~mL}$ of $100 \%$ Tween- 20 , and $890 \mathrm{~mL} \mathrm{ddH}_{2} \mathrm{O}$ ) for an hour at room temperature. After blocking, the membrane was immunostained at $4^{\circ} \mathrm{C}$ overnight with the indicated antibodies in a dilution from 1:1000 to 1:5000. After incubation with HRP labeled secondary antibody for an hour, the chemiluminscence signal was catalyzed by ECL (GE Healthcare or Millipore), and detected the level of protein expression. Phospho-EGFR Tyr992 (\#2235), Phospho-EGFR Tyr1068 (\#2236), PhosphoEGFR Tyr1086 (\#2220), Phospho-ERBB2 Tyr1221/1222 (\#2243), Phospho-ERBB3 Tyr1289 (\#4791), Akt (\#9272), Phospho-Akt ser473 (XP) (\#9271), Erk (\#9102), and Phospho-Erk T202, Y204 (\#9106s), and PARP (\#9542) were purchased from Cell signaling Technology. EGFR (sc-03), ERBB2 (sc-284), ERBB3 (sc-285) were purchased from Santa Cruz Biotechnology. Hepatitis B virus X (ab39716) was purchased from Abcam. $\alpha$-Tubulin (T6074) and $\beta$-actin (A2228) were purchased from SIGMA. Caspase-3 IMG144A was purchased from IMGENEX. Anti-c-myc (Cat No. 11667203001) was purchased from Roche.

\section{MTT assay}

Cells were seeded at density of $3 \times 10^{3} \sim 1 \times 10^{4}$ cells/ well in 96-well plate. To identify the different viability between the parental cells and HBx-expressing cells after the treatment, the culture medium was removed and $80 \mu \mathrm{l}$ of serum-free medium and $20 \mu \mathrm{l}$ of $5 \mathrm{mg} / \mathrm{mL}$ MTT solution (Sigma) were mixed and added to each well followed by incubation in $37^{\circ} \mathrm{C}$ for 3 hours. Then, MTT solution was removed and $100 \mu \mathrm{l}$ of DMSO was added to lyse the cells. After incubation for one hour, the absorbance were be detected by ELISA reader.

\section{Cell counting analysis}

The cultured medium was removed and cells were washed with phosphate buffer saline (PBS) followed by addition of appropriate trypsin-EDTA to de-attach cells from dishes. Next, cells were collected in $1.5 \mathrm{~mL}$ eppendorf and centrifuged at $16,000 \mathrm{~g}$ for 5 minutes. Supernatant were removed and the cell pallet was scattered in $100 \mu \mathrm{l}$ fresh medium, and cells were diluted with trypan blue with ratio $1: 1$. Finally, cells were count by Countess ${ }^{\mathrm{TM}}$ automated cell counter (Invitrogen, Carlsbad, CA).

\section{Cell cycle analysis}

Cells were treated with lapatinib in different dosages for 5 days. After treatment, cells were washed with PBS and trypsinized. Then, cells were collected and centrifuged followed by supernatant removal, and then $75 \%$ ethanol was added to fully fix cells. Before analyzed by flow cytometry, the cells were stained with PI buffer $(1 \%$ Triton-X 100, 0.1\%mg/mL PureLink ${ }^{\mathrm{TM}}$ RNase A (Cat no. 12091-021), and $20 \mu \mathrm{g} / \mathrm{mL}$ Propidium iodide in 1X PBS) for 30 minutes, and analyzed by Flow cytometry.

\section{Cell apoptosis assay}

Hep3B and Hep3Bx cells were treated with lapatinib for 5 days followed by wash with PBS and trypsinization. Cells were collected and cell viability was measured by staining with Annexin V-FITC Apoptosis Detection Kit (BioVision, Cat\#K101-400) for $15 \mathrm{~min}$ at room temperature.

\section{RNA extraction}

Cells were washed with PBS and added $0.5 \mathrm{~mL}$ Trizol $^{\mathrm{TM}}$ reagent (Roche) to extract total RNA followed by mix with $0.1 \mathrm{~mL}$ of chloroform to separate aqueous phase, interphase, and organic phase. Next, total RNA was precipitated from the aqueous phase by mixing with 0.25 $\mathrm{mL}$ of isopropanol. The pellet was washed with $0.5 \mathrm{~mL}$ $75 \% \mathrm{EtOH}$ for twice followed by air-dried and dissolved in DEPC-treated water.

\section{RT-qPCR (reverse transcription-quantitative polymerase chain reaction)}

After total RNA extraction, reverse transcription polymerase chain reaction was performed. The reagents in RT-PCR analysis include $1 \mu \mathrm{g}$ sample, DEPC $\mathrm{H}_{2} \mathrm{O}$, Oligo-dT, dNTP, DTT, 5X MMLV buffer, and MMLV transcriptase. All components were purchased from Roche. The cDNA products were used for real-time PCR. All sample were 10X dilute from real-time PCR product. For quantitative real-time polymerase chain reaction, SYBR Green Master Mix was used to detect the expression of indicated genes with specific primers described in the supplementary information.

\section{HCC patient samples}

The patient samples of HCC (39) and HBVassociated HCC (88) were from National Cheng Kung 
University Hospital and National Health Research Institutes. Informed consents were signed by patients with approval by the Institutional Review Board, China Medical University Hospital, Taichung, Taiwan (DMR101-IRB1-119) and by the Institutional Review Board of the Human Investigation Committee of College of Medicine, National Cheng Kung University Tainan, Taiwan (B-ER-102-210). The expressions of ErbB3 mRNA normalized respectively to GAPDH were determined in RT-qPCR analysis. The protein expression of ErbB3 and HBx were analyzed by Western blot and quantified by image $\mathrm{J}$ analysis. The differences in various HCC tumor tissues compared to the normal tissues was determined by a two-tailed Student's t test and $p<0.001$ was defined as statistically significant.

\section{Chromatin immuno-precipitation (ChIP)}

Cells were fixed with $37 \%$ formadehyde for 15 minutes at room temperature, and $1 \mathrm{M}$ glycine was used to stop the reaction followed by wash with ice-cold PBS twice. Cells were scraped off and washed by IP buffer for 3 times before sonication. Total lysate was added with $1 \mathrm{~mL}$ ChIP buffer and sonicated at $30 \mathrm{Amp}$ for total 3 minutes. After quantification, $1 \mathrm{mg}$ total lysates were immunopreciated with indicated antibody or $\operatorname{IgG}$ at $4^{\circ} \mathrm{C}$ overnight. The immunoprecipitated DNA was extracted and subjected to quantitative PCR with indicated primers.

\section{Luciferase assay}

Cells were seeded at density of $3 \times 10^{4}$ cells/well in 12-well plate. ErbB3 promoter luciferase DNA and HBx DNA were co-transfected into cells for 48 hours. The luciferase activity was measured by using Secrete-Pair ${ }^{\mathrm{TM}}$ Gaussia Luciferase Assay Kit (GeneCopoeia ${ }^{\mathrm{TM}}$ ) according to the manufacturer's protocol. For luciferase reporter assay, firefly luciferase activities were normalized with the renilla activities.

\section{Crystal violet staining assay}

To access the survival and sensitivity of cells to EGFR inhibitors, cells were seeded at low density and treated with lapatinib for 5 days. Crystal violet was used to stain live cells. The quantitation was performed by solving crystal violet with $30 \%$ acetic acid and measured by ELISA reader.

\section{Proximity ligation assay (PLA)}

Cells were seeded at density of $3 \times 10^{4}$ cells/slide. Fixed with $4 \%$ paraformaldehyde for 10 minutes at room temperature and blocking with blocking solution (Duolink ${ }^{\circledR}$ In Situ, Sigma) for 30 minutes at $37^{\circ} \mathrm{C}$ on the next day. The slides were immunostained at $4^{\circ} \mathrm{C}$ overnight with anti-ErbB3 and anti-ErbB2 specific antibodies in a dilution of $1: 100$. Added PLA probe solution (Duolink ${ }^{\circledR}$
In Situ, Sigma) and then ligation-ligase solution (Duolink ${ }^{\circledR}$ In Situ, Sigma) for 1 hour and 30 minutes, respectively. Amplify the signal by incubated with amplificationpolymerase solution (Duolink ${ }^{\circledR}$ In Situ, Sigma) at $37^{\circ} \mathrm{C}$ for 100 minutes. The visual spot were determined by confocal microcopy at absorbance $624 \mathrm{~nm}$.

\section{Statistical analysis}

The difference in relative gene expression between tumor and normal tissues was calculated by a two-tailed Student's t test. Coefficient analyses were performed for the correlation between gene expressions. All these statistical analyses were performed using Sigma Plot 10.0. $p<0.05$ was defined as statistically significant.

\section{CONFLICTS OF INTEREST}

The authors declare that there is no conflict of interests regarding the publication of this article.

\section{GRANT SUPPORTS}

This work was supported by grants from the Ministry of Science and Technology, R.O.C. (MOST-1022320-B-039-052, MOST-103-2320-B-039-001, MOST102-2911-I-002-303, and MOST-102-2320-B-214-008MY3), the National Health Research Institutes of Taiwan (NHRI-EX103-10329BI), Ministry of Health and Welfare, China Medical University Hospital Cancer Research Center of Excellence (MOHW103-TD-B-111-03), and E-Da Hospital (EDPJ103056).

\section{REFERENCES}

1. Llovet JM, Burroughs A, Bruix J Hepatocellular carcinoma. Lancet 2003; 362: 1907-1917.

2. Shariff MI, Cox IJ, Gomaa AI, Khan SA, Gedroyc W, Taylor-Robinson SD Hepatocellular carcinoma: current trends in worldwide epidemiology, risk factors, diagnosis and therapeutics. Expert Rev Gastroenterol Hepatol 2009; 3: 353-367.

3. Farazi PA, DePinho RA Hepatocellular carcinoma pathogenesis: from genes to environment. Nat Rev Cancer 2006; 6: 674-687.

4. Herceg Z, Paliwal A Epigenetic mechanisms in hepatocellular carcinoma: how environmental factors influence the epigenome. Mutat Res 2011; 727: 55-61.

5. Xu J, Liu H, Chen L, Wang S, Zhou L, Yun X, Sun L, Wen Y, Gu J Hepatitis B virus X protein confers resistance of hepatoma cells to anoikis by up-regulating and activating p21activated kinase 1. Gastroenterology 2012; 143: 199-212 e194.

6. Bruix J, Sherman M, Llovet JM, Beaugrand M, Lencioni R, Burroughs AK, Christensen E, Pagliaro L, Colombo M, Rodes J, HCC EPoEo Clinical management of hepatocellular 
carcinoma. Conclusions of the Barcelona-2000 EASL conference. European Association for the Study of the Liver. J Hepatol 2001; 35: 421-430.

7. Kuo TC, Chao CC Hepatitis B virus X protein prevents apoptosis of hepatocellular carcinoma cells by upregulating SATB1 and HURP expression. Biochem Pharmacol 2010; 80: 1093-1102.

8. Liu Y, Lou G, Wu W, Zheng M, Shi Y, Zhao D, Chen Z Involvement of the NF-kappaB pathway in multidrug resistance induced by HBx in a hepatoma cell line. J Viral Hepat 2011; 18: e439-446.

9. Diao J, Garces R, Richardson CD X protein of hepatitis B virus modulates cytokine and growth factor related signal transduction pathways during the course of viral infections and hepatocarcinogenesis. Cytokine Growth Factor Rev 2001; 12: 189-205.

10. Chen WS, Yen CJ, Chen YJ, Chen JY, Wang LY, Chiu SJ, Shih WL, Ho CY, Wei TT, Pan HL, Chien PH, Hung MC, et al. miRNA-7/21/107 contribute to HBx-induced hepatocellular carcinoma progression through suppression of maspin. Oncotarget 2015; 6: 25962-25974.

11. Cheng AL, Kang YK, Chen Z, Tsao CJ, Qin S, Kim JS, Luo R, Feng J, Ye S, Yang TS, Xu J, Sun Y, et al. Efficacy and safety of sorafenib in patients in the Asia-Pacific region with advanced hepatocellular carcinoma: a phase III randomised, double-blind, placebo-controlled trial. Lancet Oncol 2009; 10: 25-34.

12. Llovet JM, Ricci S, Mazzaferro V, Hilgard P, Gane E, Blanc JF, de Oliveira AC, Santoro A, Raoul JL, Forner A, Schwartz M, Porta C, et al. Sorafenib in advanced hepatocellular carcinoma. N Engl J Med 2008; 359: 378-390.

13. Moon WS, Rhyu KH, Kang MJ, Lee DG, Yu HC, Yeum JH, Koh GY, Tarnawski AS Overexpression of VEGF and angiopoietin 2: a key to high vascularity of hepatocellular carcinoma? Mod Pathol 2003; 16: 552-557.

14. Yamaguchi R, Yano H, Nakashima O, Akiba J, Nishida N, Kurogi M, Kojiro M Expression of vascular endothelial growth factor-C in human hepatocellular carcinoma. J Gastroenterol Hepatol 2006; 21: 152-160.

15. Shen YC, Hsu C, Cheng AL Molecular targeted therapy for advanced hepatocellular carcinoma: current status and future perspectives. J Gastroenterol 2010; 45: 794-807.

16. Dhar DK, Naora H, Yamanoi A, Ono T, Kohno H, Otani H, Nagasue N Requisite role of VEGF receptors in angiogenesis of hepatocellular carcinoma: a comparison with angiopoietin/Tie pathway. Anticancer Res 2002; 22: 379-386.

17. Tseng PL, Tai MH, Huang CC, Wang CC, Lin JW, Hung $\mathrm{CH}$, Chen $\mathrm{CH}$, Wang JH, Lu SN, Lee CM, Changchien CS, $\mathrm{Hu}$ TH Overexpression of VEGF is associated with positive p53 immunostaining in hepatocellular carcinoma (HCC) and adverse outcome of HCC patients. J Surg Oncol 2008; 98: 349-357.

18. Chaparro M, Gonzalez Moreno L, Trapero-Marugan M, Medina J, Moreno-Otero R Review article: pharmacological therapy for hepatocellular carcinoma with sorafenib and other oral agents. Aliment Pharmacol Ther 2008; 28: 1269-1277.

19. Matsuda Y, Fukumoto M Sorafenib: complexities of Rafdependent and Raf-independent signaling are now unveiled. Med Mol Morphol 2011; 44: 183-189.

20. Furuse J Sorafenib for the treatment of unresectable hepatocellular carcinoma. Biologics 2008; 2: 779-788.

21. Siegel AB, Olsen SK, Magun A, Brown RS, Jr. Sorafenib: where do we go from here? Hepatology 2010; 52: 360-369.

22. El-Serag HB Hepatocellular carcinoma. N Engl J Med 2011; 365: 1118-1127.

23. Chen KF, Chen HL, Tai WT, Feng WC, Hsu CH, Chen PJ, Cheng AL Activation of phosphatidylinositol 3-kinase/Akt signaling pathway mediates acquired resistance to sorafenib in hepatocellular carcinoma cells. J Pharmacol Exp Ther 2011; 337: 155-161.

24. Zhai B, Sun XY Mechanisms of resistance to sorafenib and the corresponding strategies in hepatocellular carcinoma. World J Hepatol 2013; 5: 345-352.

25. Wu JM, Sheng H, Saxena R, Skill NJ, Bhat-Nakshatri P, Yu M, Nakshatri H, Maluccio MA NF-kappaB inhibition in human hepatocellular carcinoma and its potential as adjunct to sorafenib based therapy. Cancer Lett 2009; 278 : 145-155.

26. Blivet-Van Eggelpoel MJ, Chettouh H, Fartoux L, Aoudjehane L, Barbu V, Rey C, Priam S, Housset C, Rosmorduc O, Desbois-Mouthon C Epidermal growth factor receptor and HER-3 restrict cell response to sorafenib in hepatocellular carcinoma cells. J Hepatol 2012; 57: 108-115.

27. Liang $Y$, Zheng $T$, Song R, Wang J, Yin D, Wang L, Liu H, Tian L, Fang X, Meng X, Jiang H, Liu J, et al. Hypoxiamediated sorafenib resistance can be overcome by EF24 through Von Hippel-Lindau tumor suppressor-dependent HIF-1alpha inhibition in hepatocellular carcinoma. Hepatology 2013; 57: 1847-1857.

28. Shi YH, Ding ZB, Zhou J, Hui B, Shi GM, Ke AW, Wang XY, Dai Z, Peng YF, Gu CY, Qiu SJ, Fan J Targeting autophagy enhances sorafenib lethality for hepatocellular carcinoma via ER stress-related apoptosis. Autophagy 2011; 7: 1159-1172.

29. van Malenstein H, Dekervel J, Verslype C, Van Cutsem E, Windmolders P, Nevens F, van Pelt J Long-term exposure to sorafenib of liver cancer cells induces resistance with epithelial-to-mesenchymal transition, increased invasion and risk of rebound growth. Cancer Lett 2013; 329: 74-83.

30. Ito Y, Takeda T, Sakon M, Tsujimoto M, Higashiyama S, Noda K, Miyoshi E, Monden M, Matsuura N Expression and clinical significance of erb-B receptor family in hepatocellular carcinoma. Br J Cancer 2001; 84: 1377-1383.

31. El-Rayes BF, LoRusso PM Targeting the epidermal growth factor receptor. Br J Cancer 2004; 91: 418-424.

32. Yarden Y, Sliwkowski MX Untangling the ErbB signalling network. Nat Rev Mol Cell Biol 2001; 2: 127-137. 
33. Huether A, Hopfner M, Baradari V, Schuppan D, Scherubl $\mathrm{H}$ EGFR blockade by cetuximab alone or as combination therapy for growth control of hepatocellular cancer. Biochem Pharmacol 2005; 70: 1568-1578.

34. Gazdar AF Epidermal growth factor receptor inhibition in lung cancer: the evolving role of individualized therapy. Cancer Metastasis Rev 2010; 29: 37-48.

35. Nahta R, Yu D, Hung MC, Hortobagyi GN, Esteva FJ Mechanisms of disease: understanding resistance to HER2targeted therapy in human breast cancer. Nat Clin Pract Oncol 2006; 3: 269-280.

36. Gerber DE Targeted therapies: a new generation of cancer treatments. Am Fam Physician 2008; 77: 311-319.

37. Skelton MR, O'Neil B Targeted therapies for hepatocellular carcinoma. Clin Adv Hematol Oncol 2008; 6: 209-218.

38. Villanueva A, Llovet JM Targeted therapies for hepatocellular carcinoma. Gastroenterology 2011; 140: 1410-1426.

39. Matsuda Y, Ichida T Impact of hepatitis B virus X protein on the DNA damage response during hepatocarcinogenesis. Med Mol Morphol 2009; 42: 138-142.

40. Yen CJ, Lin YJ, Yen CS, Tsai HW, Tsai TF, Chang KY, Huang WC, Lin PW, Chiang CW, Chang TT Hepatitis $\mathrm{B}$ virus $\mathrm{X}$ protein upregulates mTOR signaling through IKKbeta to increase cell proliferation and VEGF production in hepatocellular carcinoma. PLoS One 2012; 7: e41931.

41. Hung CM, Huang WC, Pan HL, Chien PH, Lin CW, Chen LC, Chien YF, Lin CC, Leow KH, Chen WS, Chen JY, Ho $\mathrm{CY}$, et al. Hepatitis B virus $\mathrm{X}$ upregulates HuR protein level to stabilize HER2 expression in hepatocellular carcinoma cells. Biomed Res Int 2014; 2014: 827415.

42. Chen YJ, Chien PH, Chen WS, Chien YF, Hsu YY, Wang LY, Chen JY, Lin CW, Huang TC, Yu YL, Huang WC Hepatitis B Virus-Encoded X Protein Downregulates EGFR Expression via Inducing MicroRNA-7 in Hepatocellular Carcinoma Cells. Evid Based Complement Alternat Med 2013; 2013: 682380.

43. Cheng AS, Wong N, Tse AM, Chan KY, Chan KK, Sung JJ, Chan HL RNA interference targeting HBx suppresses tumor growth and enhances cisplatin chemosensitivity in human hepatocellular carcinoma. Cancer Lett 2007; 253: 43-52.

44. Shih WL, Kuo ML, Chuang SE, Cheng AL, Doong SL Hepatitis B virus $\mathrm{X}$ protein inhibits transforming growth factor-beta -induced apoptosis through the activation of phosphatidylinositol 3-kinase pathway. J Biol Chem 2000; 275: 25858-25864.

45. Hellyer NJ, Kim MS, Koland JG Heregulin-dependent activation of phosphoinositide 3-kinase and Akt via the ErbB2/ ErbB3 co-receptor. J Biol Chem 2001; 276: 42153-42161.

46. O'Neill F, Madden SF, Aherne ST, Clynes M, Crown J, Doolan P, O'Connor R Gene expression changes as markers of early lapatinib response in a panel of breast cancer cell lines. Mol Cancer 2012; 11: 41.

47. Vaught DB, Stanford JC, Young C, Hicks DJ, Wheeler F, Rinehart C, Sanchez V, Koland J, Muller WJ, Arteaga CL,
Cook RS HER3 is required for HER2-induced preneoplastic changes to the breast epithelium and tumor formation. Cancer Res 2012; 72: 2672-2682.

48. Tzahar E, Waterman H, Chen X, Levkowitz G, Karunagaran D, Lavi S, Ratzkin BJ, Yarden Y A hierarchical network of interreceptor interactions determines signal transduction by Neu differentiation factor/neuregulin and epidermal growth factor. Mol Cell Biol 1996; 16: 5276-5287.

49. Citri A, Skaria KB, Yarden Y The deaf and the dumb: the biology of ErbB-2 and ErbB-3. Exp Cell Res 2003; 284: 54-65.

50. Krig SR, Miller JK, Frietze S, Beckett LA, Neve RM, Farnham PJ, Yaswen PI, Sweeney CA ZNF217, a candidate breast cancer oncogene amplified at 20q13, regulates expression of the ErbB3 receptor tyrosine kinase in breast cancer cells. Oncogene 2010; 29: 5500-5510.

51. Benhenda S, Cougot D, Neuveut C, Buendia MA Liver cell transformation in chronic HBV infection. Viruses 2009; 1: 630-646.

52. Su F, Schneider RJ Hepatitis B virus HBx protein activates transcription factor NF-kappaB by acting on multiple cytoplasmic inhibitors of rel-related proteins. J Virol 1996; 70: 4558-4566.

53. Benn J, Su F, Doria M, Schneider RJ Hepatitis B virus HBx protein induces transcription factor AP-1 by activation of extracellular signal-regulated and c-Jun N-terminal mitogen-activated protein kinases. J Virol 1996; 70: 4978-4985.

54. Shin GC, Ahn SH, Choi HS, Kim J, Park ES, Kim DH, Kim KH Hepatocystin contributes to interferon-mediated antiviral response to hepatitis B virus by regulating hepatocyte nuclear factor 4alpha. Biochim Biophys Acta 2014; 1842: 1648-1657.

55. You X, Liu F, Zhang T, Lv N, Liu Q, Shan C, Du Y, Kong G, Wang T, Ye L, Zhang X Hepatitis B virus X protein upregulates Lin28A/Lin28B through Sp-1/c-Myc to enhance the proliferation of hepatoma cells. Oncogene 2014; 33: 449-460.

56. Lim KH, Choi HS, Park YK, Park ES, Shin GC, Kim DH, Ahn SH, Kim KH HBx-induced NF-kappaB signaling in liver cells is potentially mediated by the ternary complex of HBx with p22-FLIP and NEMO. PLoS One 2013; 8: e57331.

57. Cho HK, Kim SY, Kyaw YY, Win AA, Koo SH, Kim HH, Cheong J HBx induces the proliferation of hepatocellular carcinoma cells via AP1 over-expressed as a result of ER stress. Biochem J 2015; 466: 115-121.

58. Shi XY, Zhang YY, Zhou XW, Lu JS, Guo ZK, Huang PT Hepatitis B virus X protein regulates the $\mathrm{mEZH} 2$ promoter via the E2F1-binding site in AML12 cells. Chin J Cancer 2011; 30: 273-279.

59. Israel A The IKK complex, a central regulator of NF-kappaB activation. Cold Spring Harb Perspect Biol 2010; 2: a000158.

60. Huang WC, Chen WS, Chen YJ, Wang LY, Hsu SC, Chen CC, Hung MC Hepatitis B virus X protein induces 
IKKalpha nuclear translocation via Akt-dependent phosphorylation to promote the motility of hepatocarcinoma cells. J Cell Physiol 2012; 227: 1446-1454.

61. Worns MA, Galle PR Novel inhibitors in development for hepatocellular carcinoma. Expert Opin Investig Drugs 2010; 19: 615-629.

62. Zhu AX Beyond sorafenib: novel targeted therapies for advanced hepatocellular carcinoma. Expert Opin Investig Drugs 2010; 19: 663-672.

63. Lee SC, Lim SG, Soo R, Hsieh WS, Guo JY, Putti T, Tao Q, Soong R, Goh BC Lack of somatic mutations in EGFR tyrosine kinase domain in hepatocellular and nasopharyngeal carcinoma. Pharmacogenet Genomics 2006; 16: 73-74.

64. Kim H, Lim HY Novel EGFR-TK inhibitor EKB-569 inhibits hepatocellular carcinoma cell proliferation by AKT and MAPK pathways. J Korean Med Sci 2011; 26: 1563-1568.

65. Ahn SY, Cho CH, Park KG, Lee HJ, Lee S, Park SK, Lee IK, Koh GY Tumor necrosis factor-alpha induces fractalkine expression preferentially in arterial endothelial cells and mithramycin A suppresses TNF-alpha-induced fractalkine expression. Am J Pathol 2004; 164: 1663-1672.

66. Wu HL, Chen PJ, Lin MH, Chen DS Temporal aspects of major viral transcript expression in Hep G2 cells transfected with cloned hepatitis B virus DNA: with emphasis on the $\mathrm{X}$ transcript. Virology 1991; 185: 644-651.

67. Sze KM, Chu GK, Lee JM, Ng IO C-terminal truncated hepatitis $\mathrm{B}$ virus $\mathrm{x}$ protein is associated with metastasis and enhances invasiveness by C-Jun/matrix metalloproteinase protein 10 activation in hepatocellular carcinoma. Hepatology 2013; 57: 131-139.

68. Ma NF, Lau SH, Hu L, Xie D, Wu J, Yang J, Wang Y, Wu MC, Fung J, Bai X, Tzang CH, Fu L, et al. COOH-terminal truncated HBV X protein plays key role in hepatocarcinogenesis. Clin Cancer Res 2008; 14: 5061-5068.

69. Tu H, Bonura C, Giannini C, Mouly H, Soussan P, Kew M, Paterlini-Brechot P, Brechot C, Kremsdorf D Biological impact of natural $\mathrm{COOH}$-terminal deletions of hepatitis $\mathrm{B}$ virus X protein in hepatocellular carcinoma tissues. Cancer Res 2001; 61: 7803-7810. 